\title{
An Innovative IMTA System: Polychaetes, Sponges and Macroalgae Co-Cultured in a Southern Italian In-Shore Mariculture Plant (Ionian Sea)
}

\author{
Adriana Giangrande ${ }^{1}$, Cataldo Pierri ${ }^{2, *}{ }^{2}$, Daniele Arduini ${ }^{1}$, Jacopo Borghese ${ }^{1}$, \\ Margherita Licciano ${ }^{1} \mathbb{D}$, Roberta Trani ${ }^{2} \mathbb{D}$, Giuseppe Corriero ${ }^{2}$, Grazia Basile ${ }^{3}$, Ester Cecere ${ }^{4}$, \\ Antonella Petrocelli ${ }^{4, * \mathbb{D}}$, Loredana Stabili ${ }^{1,4}$ and Caterina Longo ${ }^{2}$ \\ 1 Department of Biological and Environmental Sciences and Technologies, University of Salento, \\ Via Provinciale Lecce-Monteroni, 73100 Lecce, Italy; adriana.giangrande@unisalento.it (A.G.); \\ daniele.arduini@studenti.unisalento.it (D.A.); borghesejacopo@gmail.com (J.B.); \\ margherita.licciano@unisalento.it (M.L.); loredana.stabili@irsa.cnr.it (L.S.) \\ 2 Department of Biology, University of Bari Aldo Moro, Via Orabona 4, 70125 Bari, Italy; \\ roby.trani@libero.it (R.T.); giuseppe.corriero@uniba.it (G.C.); caterina.longo@uniba.it (C.L.) \\ 3 Maricoltura Mar Grande Scarl, Via Jonio, 74100 San Vito (TA), Italy; info@gigantesrl.it \\ 4 Institute for Water Research (IRSA)—CNR, Via Roma 3, 74123 Taranto, Italy; ester.cecere@irsa.cnr.it \\ * Correspondence: cataldo.pierri@uniba.it (C.P.); antonella.petrocelli@irsa.cnr.it (A.P.)
}

Received: 6 September 2020; Accepted: 21 September 2020; Published: 23 September 2020

\begin{abstract}
In this paper, we report data from the first year of rearing of a set of filter feeder bioremediator organisms: macrobenthic invertebrates (sabellid polychaetes and sponges), coupled with macroalgae, realized in a mariculture fish farm. This innovative integrated multi-trophic aquaculture (IMTA) system was realized at a preindustrial level in the Gulf of Taranto (southern Italy, northern Ionian Sea), within the framework of the EU Remedia Life project. Long lines containing different collector typologies were placed around the fish breeding cages. Vertical collectors were utilized for both polychaetes and sponges, whilst macroalgae were cultivated in horizontal collectors. Data on the growth and mortality of the target species after the first year of rearing and cultivation are given together with their biomass estimation. Polychaete biomass was obtained from natural settlement on ropes previously hung in the system, while sponges and macroalgae were derived from explants and/or inocules inserted in the collectors. The description of the successional pattern occurring on collectors used for settling until reaching a "stable" point is also described, with indications of additional filter feeder macroinvertebrates other than polychaetes and sponges that are easily obtainable and useful in the system as bioremediators as well. The results demonstrate an easy, natural obtaining of large biomass of sabellid polychaetes settling especially from about a 4 to $10 \mathrm{~m}$ depth. Sponges and macroalgae need to be periodically cleaned from the fouling covering. The macroalgae cycle was different from that of invertebrates and requires the cultivation of two different species with about a 6-month cycle for each one. The present study represents one of the first attempts at IMTA in the Mediterranean area where invertebrates and macroalgae are co-cultured in an inshore fish farm. Possible utilization of the produced biomass is also suggested.
\end{abstract}

Keywords: integrated multi-trophic aquaculture; Mediterranean Sea; sponges; polychaetae; macroalgae; bioremediation

\section{Introduction}

The strong growth of the mariculture industry calls for the development of new strategies to control and minimize the impact of this activity on the environment [1,2]. The first step of this process should 
be the replacement of monoculture with polyculture, and the integrated multi-trophic aquaculture (IMTA) technique fall into this philosophy [3-6]. The IMTA technique consists of combining the cultivation of fed aquaculture species associated with other species able to extract organic and/or inorganic substances from seawater. This practice is aimed to improve environmental quality, economic return and social suitability $[7,8]$.

In the current literature, mariculture bioremediation focused especially on sediment restoration and on the role of the detritivore community [9-14]. However, according to recent practical approaches, a bioremediation effect on the water column can also be corroborated, especially in environments submitted to lateral drift, where nutrient loading can be efficiently exploited directly by the filter feeders' community [15-18]. For this purpose, in recent decades, there has been an increasing interest in promoting the growth of biofouling on devoted artificial structures [6,18-28]. Considering the extreme spatial and temporal variability of fouling, to reach good performances, the planned system should be based on knowledge of the environmental and biological characteristics of the area [29-33].

IMTA systems are not immune from criticisms deriving from the large number of collectors that should be placed to produce acceptable quantities of biomass for an efficient bioremediation. Moreover, to promote a circular economy, the IMTA approach is, today, based only on economically viable aquaculture species [7], such as edible filter feeders, particularly molluscs [3,6,34]. Moreover, it was proven that the polyculture of fin fish and bivalves does not represent an appropriate tool for reducing the environmental impact of fin fish aquaculture [29].

The present paper refers to an innovative IMTA rearing model, performed at a preindustrial level within the EU Remedia Life project (LIFE16 ENV/IT/000343) ongoing in the Gulf of Taranto (Ionian Sea), where a new set of bioremediators, such as polychaetes, sponges and macroalgae, coupled with mussels, has been proposed within a fish farm for the first time at the European level, with a tentative aim to also utilize the fouling natural settling on collectors, which is still considered a negative factor. Indeed, the fouling directly settled on the cages can reduce water flow, thus negatively affecting production, especially due to the periodical mechanical cleaning actions required for biofouling removal [35]. The main target organisms, e.g., sabellids, sponges and macroalgae, have been the object of numerous investigations by our research groups in relation to marine aquaculture waste treatment for about 20 years. Filter feeder polychaetes [36-40] and sponges [41-44] can act on organic particulate matter and bacteria. As concerns macroalgae, bioremediation of nutrient-rich aquaculture wastewater (ammonium, nitrate and phosphate) was demonstrated to be effective at a laboratory scale [45-48].

Sabellids are also ideal candidates for IMTA purposes due to the high density that they can reach on artificial substrates in eutrophic environments, where they can be easily obtained. Moreover, although further studies on the possible use of their biomass are still being performed, first investigations on their biochemical composition indicated their possible employment as a dietary supplement for fish nourishment [49]; this is also a very attractive suggestion considering the need for sustainable alternatives to fishmeal [50]. However, the possibility of using large quantities of biomass for these purposes must deal with the need not to deplete natural stocks. The first attempt of sabellid rearing was carried out in a land-based fish farm with recycled water [36], but it was also conducted at a small scale in the sea [51] and coupled with a mollusc farm [52].

As concerns sponges, findings obtained from about 20 years of field and laboratory research on more than 30 sponge species by Italian and international researcher teams suggest that in situ sponge-culture may be suitable for the eco-sustainable supply chain of sponge biomass for some target species [44,53-57]. The sponge biomass obtained in polyculture systems has considerable potential from a commercial point of view, having good appeal for cosmetic or hobbyist production of natural biocides, or for the pharmaceutical industry thanks to their bioactive compounds. Among marine invertebrates, sponges and their microbiome are one of the main producers of natural bioactive compounds, and, indeed, among about 7000 chemical compounds derived from marine organisms, more than $30 \%$ have been isolated from sponges [58]. 
Finally, the role of marine macroalgae in offering good ecosystem services is well known; they enrich seawater with oxygen, naturally mitigate nutrient excess and are increasingly used in the bioremediation of chemical pollution $[59,60]$. Their biomass is recognized as a good stock of bio-products $[60,61]$, useful in different biotechnological applications in medicine, cosmetics or formulation of nutraceuticals and human food products [49,62-64]. However, to become marketable, biomass needs to be produced in considerable quantities, therefore, macroalgae are suitable candidates for mass production in sustainable multitrophic aquaculture plants [65].

A pilot attempt of IMTA with seaweed was carried out in the USA at the end of the 1970s [66], while in Israel, these organisms were introduced in IMTA from the mid-1980s [67,68]. Since then, most integrated polycultures were performed in Asia and Canada $[8,59,69,70]$. In Europe, a recent survey showed that several constraints of different kinds slowed down the application of such technology; only few sea-based experimental farms were set up with seaweeds, of which only two had a commercial perspective in Atlantic waters [71]. A first attempt of seaweed polyculture in the Mediterranean area refers to the Mar Piccolo of Taranto, where the species Gracilaria dura was co-cultured with Mytilus galloprovincialis and Sabella spallanzanii [72].

In the present paper, data on the first cycle of production of sabellids, sponges and seaweeds, obtained in the framework of the Remedia Life project, are reported. In particular, this early period of setting up this innovative rearing plant aimed to provide answers to several crucial points: (1) to investigate the most simple culturing methods compatible with fish production; (2) to determine which species could be obtained in a natural way and how macrobenthic settlers can interfere with target species; (3) to establish the amount of biomass that can be produced at large scale, to estimate the best cycle length of the production.

\section{Material and Methods}

\subsection{Study Area}

The study area is located on the south-west side of the Mar Grande of Taranto $\left(40^{\circ} 25^{\prime} 56^{\prime \prime} \mathrm{N}\right.$; $17^{\circ} 14^{\prime} 19^{\prime \prime}$ E) (Ionian Sea), which is part of one of the most important coastal marine ecosystems along the Apulian coast (Figure 1). The Mar Grande of Taranto is a semi-enclosed basin connected to the Gulf of Taranto through three artificial dams. The temperature shows seasonal variations typical of the coastal Ionian regions with an average annual value of about $18{ }^{\circ} \mathrm{C}$, while the salinity is about $38 \%$ ond is almost uniform over the year. The area is affected by intense Mytilus galloprovincialis farming, a species that finds, in the area, optimal conditions to dominate the final stage of the shallow local fouling communities, sometimes competing with solitary ascidians as well as with sabellid polychaetes [73-75].

The investigation was performed in the aquaculture plant Maricoltura del Mar Grande, which is a partner of the Remedia Life project hosting the experimentation of the innovative IMTA system. The plant covers a surface of $0.06 \mathrm{Km}^{2}$ and is located in a semi-confined area of the Mar Grande, positioned at about $600 \mathrm{~m}$ away from the coast. It consists of 15 cages $(\varnothing 22 \mathrm{~m})$, working at a depth ranging from 7 to $12 \mathrm{~m}$ and producing about 100 tons $^{*} \mathrm{year}^{-1}$ of European seabass Dicentrarchus labrax (Linnaeus, 1758) or sea bream Sparus aurata, Linnaeus, 1758.

\subsection{Field Work: Sampling and Processing}

With one of the goals of the Remedia Life project being the estimation of the mitigation of aquaculture wastes, the experimental design was planned after the realization of a large monitoring survey performed to individuate the best area for the placement of rearing structures [76]. During the ex ante survey, the first step concerned an analysis of the hydro dynamism of the area together with measurements of the physico-chemical parameters. Both water column (bacterial component and nutrients) and sediment (bacterial community and taxonomic structure of the benthic assemblages) parameters were also investigated to be compared to the situation after the bioremediation activity. 

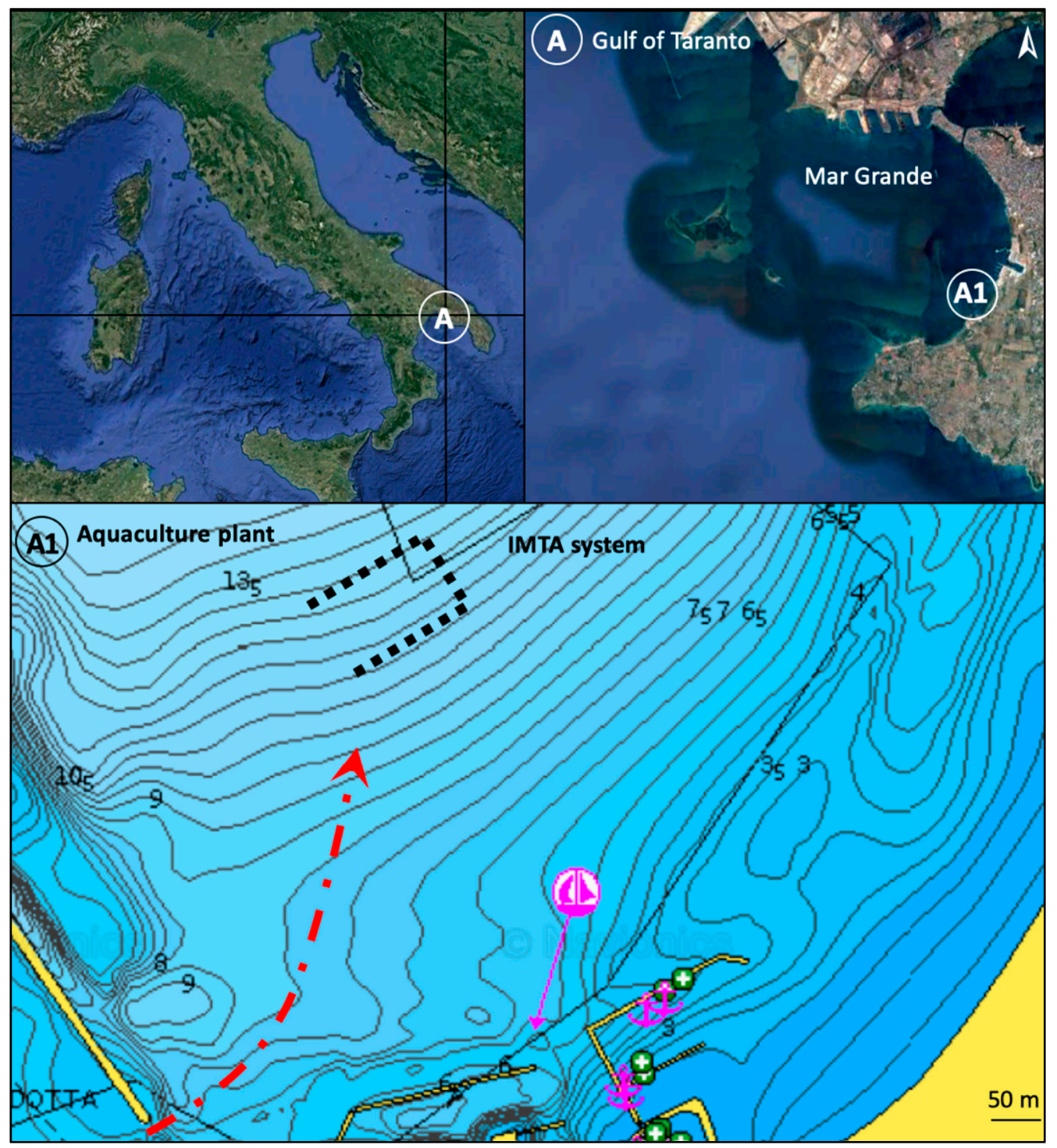

Figure 1. Map of the study site. The dashed red arrow indicates the direction of the dominant current on the bottom.

The hydrodynamic analysis has shown that in the area, the surface current is directed from the north-east to the south-west at a speed of about $3 \mathrm{~cm} \mathrm{~s}^{-1}$. At the bottom, the direction of the current is inverted, proceeding from south-west to north-east at a speed of about $1.3 \mathrm{~cm} \mathrm{~s}^{-1}$. The results of the ex ante monitoring revealed which was the more impacted site in terms of bacterial, inorganic and organic compound concentration, specific richness of soft-bottom macrobenthic communities and fouling taxonomic structure (unpublished data). Macroinvertebrates and seaweeds were added in this area, which is considered the treatment site (T). Here, three long lines, named LLA, LLB and LLC, were realized and placed around six cages. Another six cages, separated by an additional line of cages, acted as the control (C) (Figure 2A).

The Remedia Life plant, placed around the treatment $(\mathrm{T})$ cages, was supported by buoys to avoid the sinking of the structure following the increase of the biomass raised (Figure 2B). The space between two consecutive buoys constituted a breeding "chamber" to house the invertebrates and macroalgae modules, represented by vertical collectors for macrobenthic rearing (bare collectors for the recruitment of polychaetes and modules with explant of sponges and macroalgae) (Figure 2C). In each chamber, several retinas of $5 \mathrm{~m}$ length containing molluscs were also placed alternating with polychaetes and 
sponges in order to fill empty space, a relevant component of the local fouling. Macroalgae were instead placed at the surface within plastic socks.

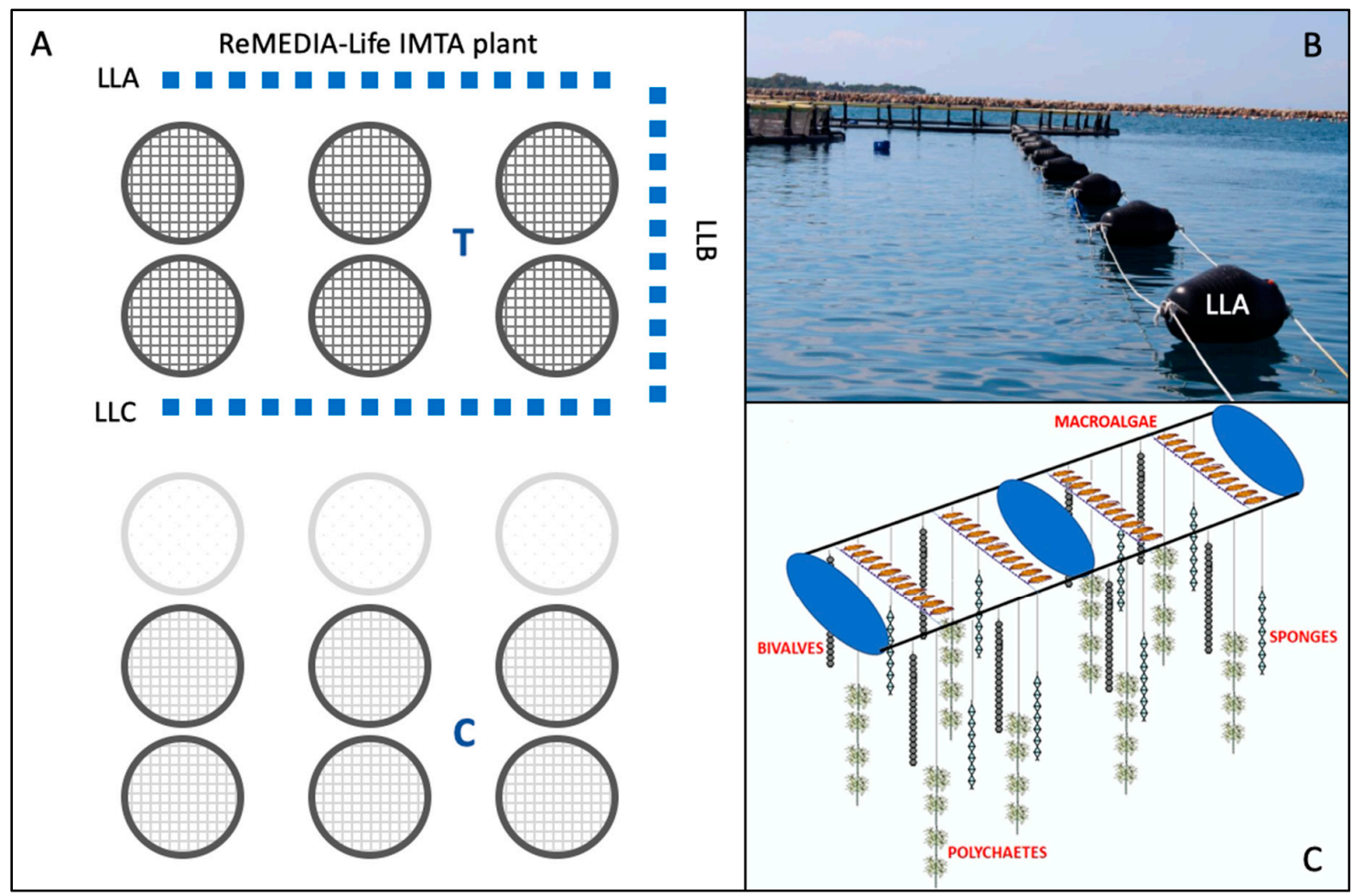

Figure 2. (A) Map of the plant with indications of the long lines and the two areas (T: treatment and C: control); (B) a photo of the external long line; (C) scheme of a rearing unit (chamber) with the disposition of invertebrates and macroalgae.

A total of 196 bare collectors (76 modules in the LLA, 54 in the LLB, 66 in the LLC) consisting of coconut fibre ropes, $2 \mathrm{~cm}$ wide and $10 \mathrm{~m}$ long, were placed for macroinvertebrate settlement and, in particular, for polychaete sabellid rearing. For this purpose, adult worms of the species Sabella spallanzanii collected around the area were inserted in the last meter of their length, acting as spawners and enhancing self-settlement on the collectors (Figure 3A). This species was chosen because it represents a natural and abundant element of the fouling communities all around in the area [73-75,77]. Of the 196 collectors, only 184 were followed until the end of the year cycle because some of them were utilized for a previous experimentation on S. spallanzanii biomass [78].

The sponge-rearing modules consisted of $7 \mathrm{~m}$ long ropes (Figure 3B) in which sponge explants were inserted within plastic nets at regular intervals every $40 \mathrm{~cm}$, each counting a total of 12-15 explants. Among the species relatively common on the artificial and natural hard substrates of the area, the horny sponge Sarcotragus spinosulus Schmidt, 1862 (Porifera, Demospongiae, Keratosa, Dictyioceratida, Irciniidae) was tested due to its spread and potential for biomass exploitation [79-81]. The donor sponges were collected near the plant by scuba divers, according to Corriero et al. [55], from artificial substrates, such as iron poles and concrete boulders, avoiding picking up natural hard substrates. Once the donor specimens were collected, they were cut into fragments of uniform volume (about 150 $\mathrm{mL}$ ) and fixed to the rearing modules with clamps. In total, 172 modules were inserted, containing about 2000 explants of sponge (72 modules in the LLA, 56 in the LLB, 44 in the LLC).

Macroalgae were collected among the most abundant unattached species living in the Mar Piccolo (Mediterranean Sea, northern Ionian Sea, Italy), a semi-enclosed basin with lagoon features [82]. Once collected, the macroalgae were transferred to the aquaculture farm to set up the cultivation 
sockets, each consisting of seaweed enclosed into a net sack and hung with a festoon arrangement at about a $1 \mathrm{~m}$ depth.

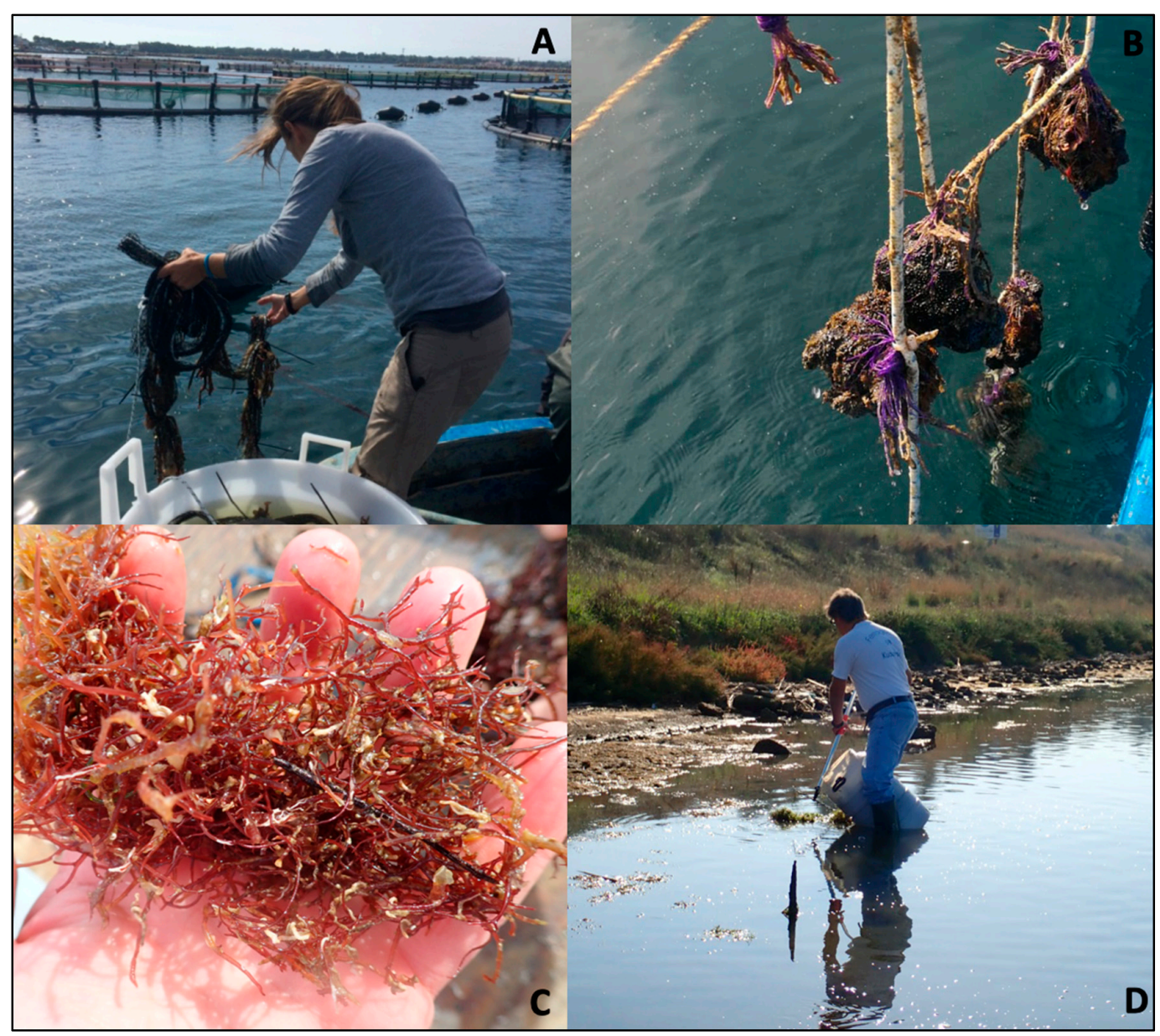

Figure 3. Some phases of in situ retinas preparation: (A) placement of vertical bare collectors with adult polychaetes at the base; (B) a module with sponges; (C) part of a drifting mattresses of Gracilaria bursa-pastoris; (D) seaweed harvesting within the Mar Piccolo.

Two different species were tested, i.e., Chaetomorpha linum (Chlorophyta, Cladophorales) and Gracilaria bursa-pastoris (Rhodophyta, Gracilariales), in two different seasons of the year due to their diverse life cycle. A total of 186 cultivation sockets ( 99 for C. linum and 87 for G. bursa-pastoris) were allocated in the plant. In particular, C. linum cultivation lasted from October 2018 until March 2019, while G. bursa-pastoris was cultivated in the plant from April 2019 until September 2019. Since during the season of maximum growth, both C. linum (i.e., early autumn) and G. bursa-pastoris (i.e., early spring) commonly make large and thick drifting mattresses (Figure 3C), it was easy to hand-collect their thalli at a $50 \mathrm{~cm}$ depth by means of a rake (Figure 3D).

The study started in October 2018 when the natural fibre collectors, sponge-rearing modules and macroalgae collectors were immersed.

Macrofouling colonization has been monitored on natural fibre collectors beginning from December 2018 in the external (LLA) and internal (LLC) long lines. The monitoring was performed using a digital camera. Fifty-centimeter-long portions of collectors were photographed in vivo at two different depths $(0 \mathrm{~m}$ and $10 \mathrm{~m})$ and 3 replicates for each long-line were taken 5 different times, corresponding to the months of December, February, March, April and June. Twelve photographs were taken each time for a total of 60 photographs. The photographs were analyzed using the software ImageJ [83], which determined the percent coverage of the sessile organisms that were identified to species level 
when possible. Thus, the coverage matrices of each species detected were obtained. The total area was $100 \mathrm{~cm}^{2}$. A multi-layer coverage was considered, with a potential coverage area greater than $100 \%$.

Starting from April 2019, when polychaete sabellids become easily recognizable, worm density was measured in situ along $1 \mathrm{~m}$ of the rope, considering three replicates randomly chosen from both the long lines. Moreover, about 50 individuals were randomly collected each time from each long line and taken to the laboratory for length and weight measurements. During this sampling phase, the health status of the worms was also controlled. At the end of the first annual cycle (December 2019), half of the coconut ropes were removed and worms were separated and extracted from the tube for biomass estimation. The other structures were maintained in the system in order to measure the growing parameters during the second year of life and to keep some adult worms to continue the bioremediation activity.

As concerns sponges, starting from January up to December 2019, the modules were monitored to check the well-being of the explants (assessed through visual observation of the healing of the cutting surface), the survival (living, dead or damaged) and the specific growth rate (SGR), valuated as $\left[(\mathrm{Vf}-\mathrm{Vi})^{*} \mathrm{Vi}^{-1} / \mathrm{t}\right]^{*} 100(\mathrm{Vi}=$ initial Volume; $\mathrm{Vf}=$ final Volume; $\mathrm{t}=$ days of rearing $)$, of randomly selected samples. In the case of wholly healed cuts and absence of stress factors (unhealed cutting surfaces, presence of areas with bacterial microfilm or exposed skeletal tissue), the individuals were defined as living; those with evident signs of stress were instead considered damaged. Starting from March 2019, the sponge rearing modules were affected by the recruitment of fouling, and, to avoid suffocation of the sponges' explants, the modules were regularly cleaned by operating in immersion to prevent stress.

Bimonthly monitoring of the well-being and growth of seaweeds was also performed. In particular, well-being was assessed both in situ, by observing the consistency and coloring of the algae in the field, and in the laboratory, by microscopic observation of cells and chloroplasts. When thalli fragmentation was observed, followed by a rapid decay, cultivation was stopped. Macroalgae biomass was measured every two weeks on three socks (one for each long line), randomly collected, and the increase was calculated as the specific growth rate (SGR), referring to the average percentage increase in weight/day according to the following formula: SGR $=\left[(\mathrm{FWt} / \mathrm{FW} 0) 1 / \mathrm{t}^{-1}\right] \times 100 . \quad(\mathrm{FWt}=$ final Fresh Weight; FW0 = initial Fresh Weight; $\mathrm{t}=$ days of immersion) [84].

\section{Results}

\subsection{Collector Colonization and Growth of Sabellid Worms}

During the starting phase of collector colonization, 40 macroinvertebrate taxa and four macroalgae were sampled, 3 of which formed the early algal turf. Among the collected taxa, the ascidiacea was the most represented taxon with 19 species, while sponges were represented by only the species Paraleucilla magna. Most of the recorded species were typical fouler species, such as Mytilus galloprovincialis, Sabella spallanzanii, Hydroides elegans and Phallusia mammillata.

The coverage percent value linearly increased, reaching 95\% in June, after eight months of colonization (Figure 4A). By contrast, species richness increases were more irregular (Figure 4B). At the beginning, few early colonizing species, such as the bryozoan Bugulina calathus and the ascidian Ascidia conchilega growing on a considerable algal felt, contributed to the coverage at all depths and in both of the examined long-lines, leading to a high similarity among the long lines' colonization. After eight months, the community had reached its end point with 25 taxa covering the substrate, with $S$. spallanzanii and M. galloprovincialis as the dominant species, both of them showing a similar increasing trend from December to June, even if with different distributions (Figure 4C). Sabella spallanzanii coverage was only $1 \%$ at the surface, becoming dominant under $4 \mathrm{~m}$ depth $(64 \%)$. A reverse trend was observed for M. galloprovincialis (65\% at the surface and $2 \%$ deeper). Intermixed with S. spallanzanii, other sabellids, such as Branchiomma luctuosum, were also found, but with only about a $4 \%$ coverage. At this stage of the community's development, the solitary ascidians P. mammillata and Styela plicata, unlike the colonial ones, remained abundant, the first one in the deeper assemblages and the second in 
the shallower assemblages. Moreover, some edible molluscs, such as Ostrea edulis and Limaria hians, were found in abundance along the whole collector.

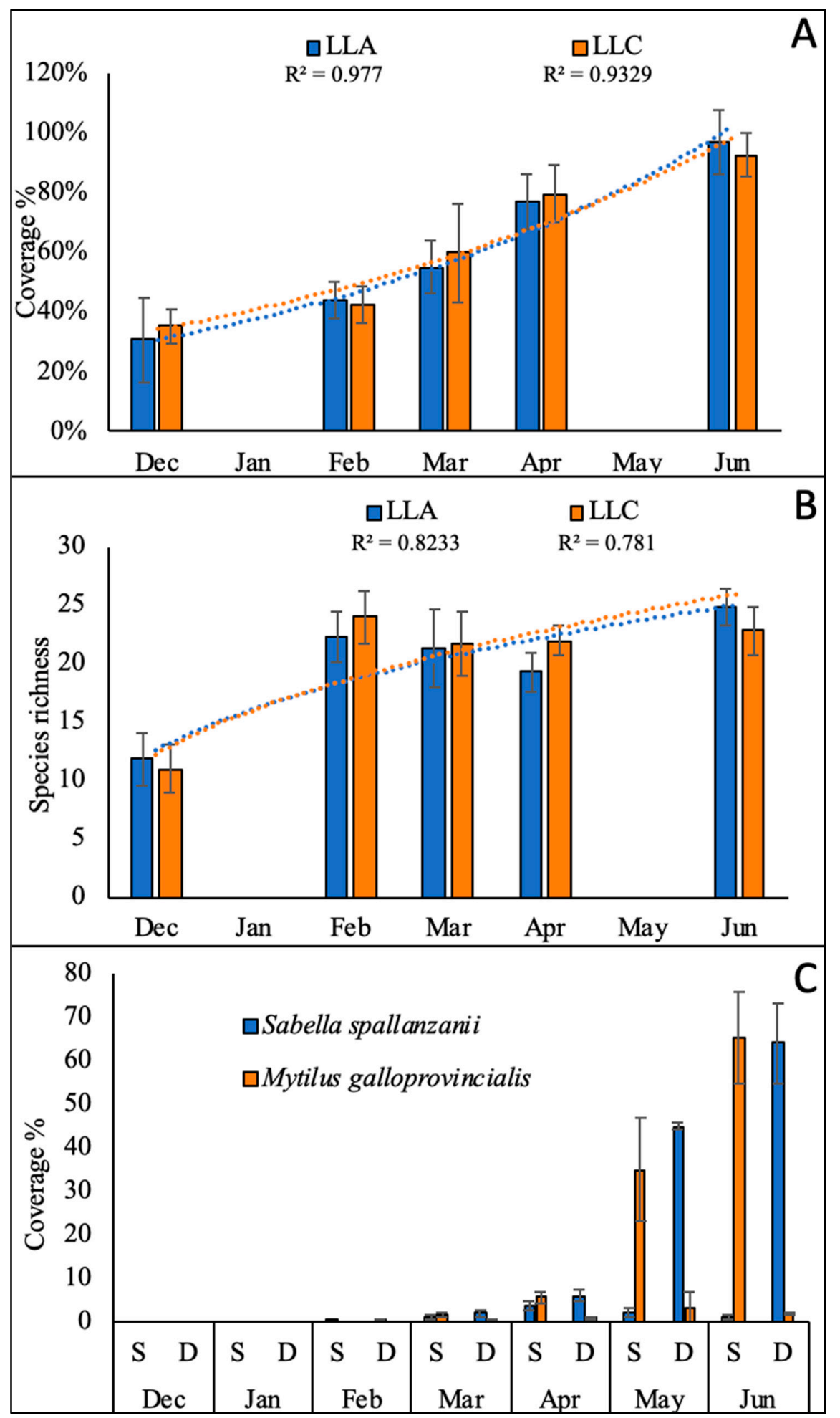

Figure 4. Mean trend over time of macrofouling: (A) percent coverage; (B) species richness; (C) percent coverage at different depths $(\mathrm{D}=$ deep, $\mathrm{S}=$ shallow) of Sabella spallanzanii and Mytilus galloprovincialis in relation with sampling time. 
The successional pattern has similar results in both of the examined long lines, with neither variation in species composition nor in abundance; the main difference in the two investigated LLs was observed during the first and intermediate stage of colonization, with a conspicuous presence of colonial ascidians, mainly Didemnum coriaceum, Diplosoma listerianum and Botrylloides leachii, in LLC. The distribution present in June 2019, with the shallow part of the collectors composed of $90 \%$ molluscs (mainly mussels) and the more in-depth community (below $4 \mathrm{~m}$ depth) contained 80\% sabellid polychaetes, among which $90 \%$ consisted of S. spallanzanii (Figure 5A), was maintained until the following month of December 2019.

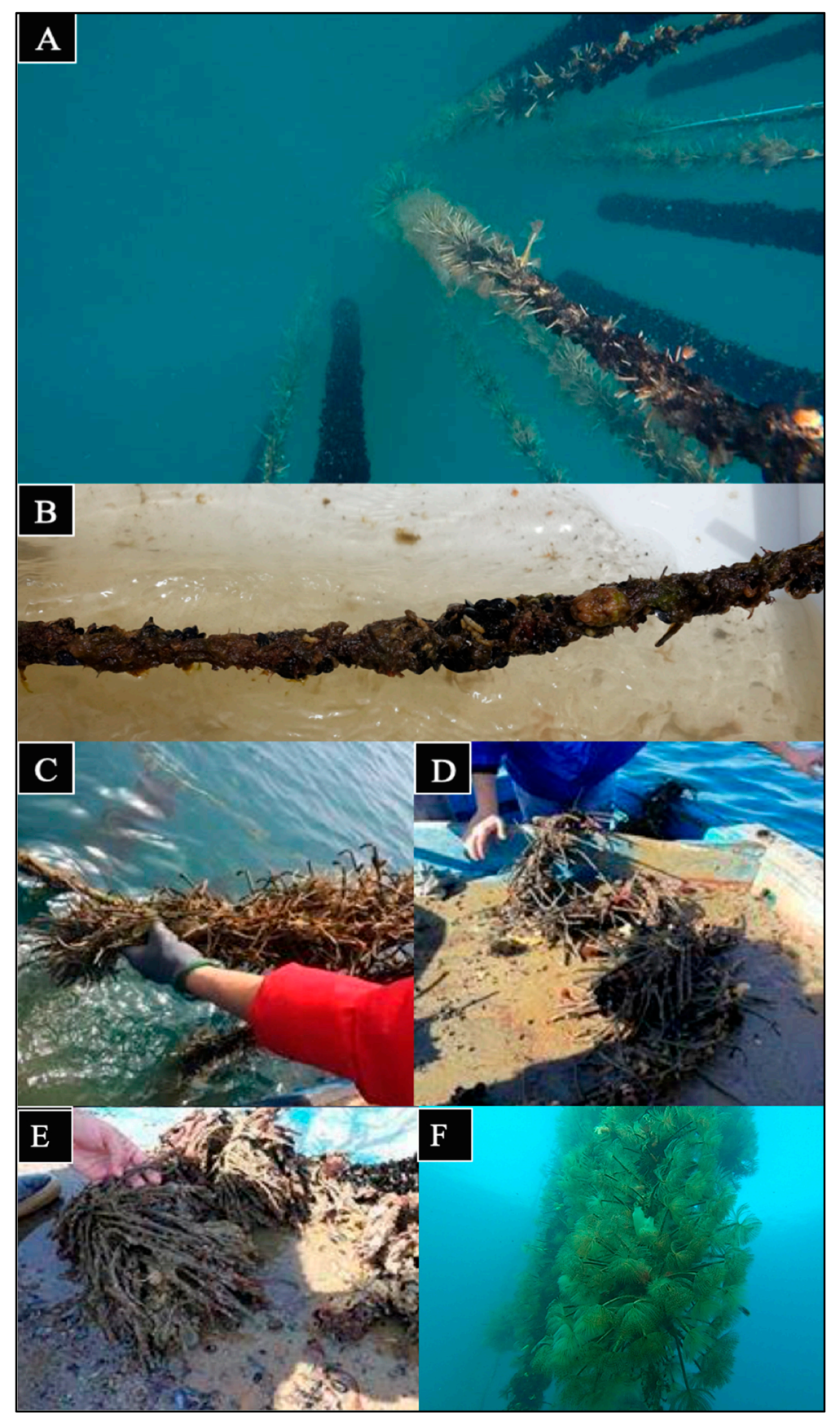

Figure 5. Collectors for fouling recruitment and Sabella spallanzanii rearing. (A) view of collectors from July 2019 showing the zonation of the two dominant species S. spallanzanii and Mytilus galloprovincialis; (B) collector from February 2019; (C,D) collectors from May and July 2019; (E) tube of S. spallanzanii covered by mud in August 2019; (F) photograph of a collector in December 2019. 
Although recruits of S. spallanzanii were probably already present on the collectors starting from February [52], during the earlier stages of colonization, individuals were too small to be detected by photograph analysis (Figure 5B). Therefore, measurements of increasing length and weight of this species began starting from April 2019, when the specimens were more manageable (Figure 5C-E). Their growth was followed up until December 2019, when the species reached up to $10 \mathrm{~cm}$ in length and $2.5 \mathrm{~g}$ in wet weight (Figure 5F). The increase in size ( $\mathrm{cm} \pm \mathrm{SD}$ ) was quite linear (Figure 6A); by contrast, increases in weight $(\mathrm{g} \pm \mathrm{SD}$ ) became more evident starting from October 2019 (Figure 6B). Both trends were very similar in the two long lines examined, even if the growth appeared slightly higher in the external one.

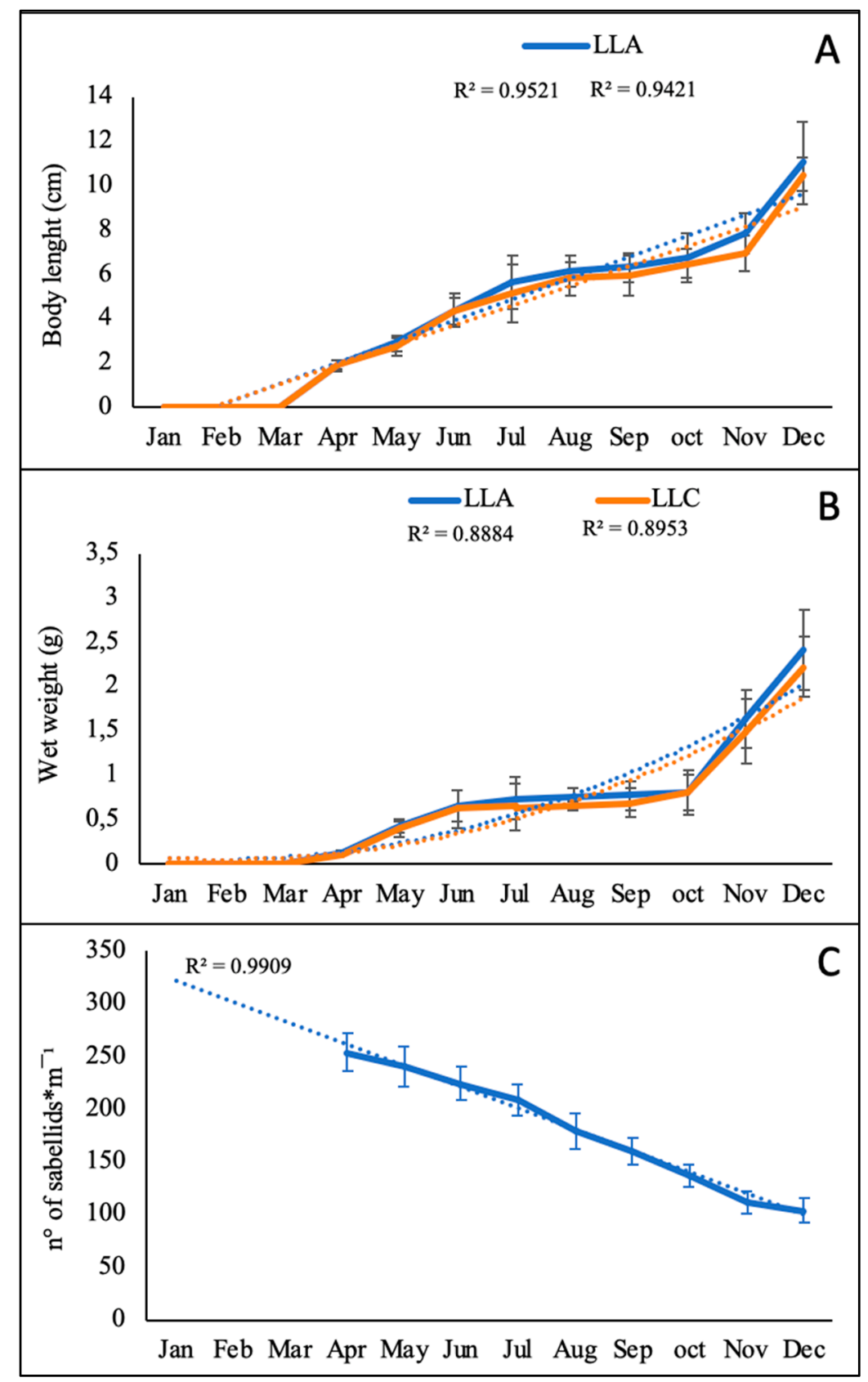

Figure 6. (A) body length increase; (B) biomass increase; (C) trend of density of Sabella spallanzanii.

The first density measurements were also relative to April 2019, which was the first month showing easily identifiable worms on the collectors. In this month, a density of about 250 worms per 
linear meter occurred. This value remained relatively constant in July and then there was a decrease, leading to the number of 100 worms at the end of the first year (Figure 6C). Therefore, from June to December, a 50\% mortality rate could be computed.

During this first year of measurements and control, the worms never showed signs of physiological discomfort and always had a withdrawal response in the tube. Moreover, even if other fouler organisms settled on their tubes, they never suffocated them. The only negative factor observed was the detachment of some tubes from the collectors because of the weight of the whole fouling. The worms remained healthy even during summer 2019, when the whole area faced a crisis related to high temperatures and the collectors were covered by a dense, muddy layer (Figure 5E), as well as during the conspicuous bloom of the red alga Spyridia filamentosa which occurred from late summer to early autumn. Even after these environmental stressing conditions, the whole fouling community maintained the above-described pattern.

From the values of biomass and density measured in half of the immersed structures, at the end of the first cycle (December 2019), a total production of about 147,000 worms was computed, with an estimated biomass of about 3.6 quintals, a production referring to the worms depleted from the tubes. During the harvesting of this first annual production, other than polychaetes, the biomass of other invertebrates, estimated at least $15 \mathrm{~L}$ for each collector, was also collected. This biomass was composed mainly of ascidians, especially P. mammillata and S. plicata, but also bryozoan and molluscs, especially the above reported O. edulis and L. hians, as well as some different sponges from the cultured species. Moreover, together with sessile filter feeder invertebrates, a conspicuous number of vagile taxa, such as echinoderms and crustaceans, were found colonizing the entire length of the collectors, especially when the macroalga S. filamentosa was highly developed.

Lastly, it is interesting to underline that when the worms were collected for biomass estimation at the end of the first annual cycle, the assemblage present on the collectors had trapped a large amount of mud, weighing at least $3 \mathrm{~kg}$ for each collector.

\subsection{Growing of the Sponges}

The monthly monitoring of the well-being and growth of the reared S. spinosulus explants showed high rearing performances, with increased survival values and noteworthy increases in biomass in short time intervals. During the entire period of observation, the mean value of living sponge explants ranged between $93 \%$ and $80.84 \%$ in January and December 2019, respectively. Besides, the highest mean value of damaged explants was registered during the first months of rearing (ranging between $23 \%$ and $16.66 \%$ ) while it reduced drastically from April onwards, down to values close to zero (Figure 7A).

In March 2019, the percentage of living explants reached $87.18 \%$ and that of damaged or exposed skeleton areas reached $16.66 \%$. In this month, the sponge-rearing modules began to be covered with abundant mucilage, particularly those placed in long line C. The percentage of living explants reached $87.23 \%$ and that of damaged ones dropped to $11.45 \%$. Starting from May, the value of damaged explants dropped drastically, while live ones showed only a slight decrease, despite the algal bloom and the dystrophic crisis recorded during the summer months.

The sponge explant specific growth rate is shown in Figure 7B; the graph clearly shows that an initial volume loss occurred as a consequence of the stress due to the collection and cutting of donor sponges into uniform explants. Starting from February, a continuous positive trend in both LLA and LLC was registered. At the end of the observation period, the explants left in the rearing modules were more than double the initial volume, going from an initial value of about $100 \pm 10 \mathrm{~mL}$ to about $240 \pm 20 \mathrm{~mL}$ (average $\pm \mathrm{SD}$ ). The overall volume $(\mathrm{mL})$ of a pool of samples progressively increased, ranging from $1180 \mathrm{~mL}$, recorded in January, to the value of $1540 \mathrm{~mL}$. It must be noticed that, since April 2019, sponge rearing modules appeared covered by fouling, and recruits of S. spallanzanii and monthly cleaning operations were carried out until December 2019 (Figure 8). 


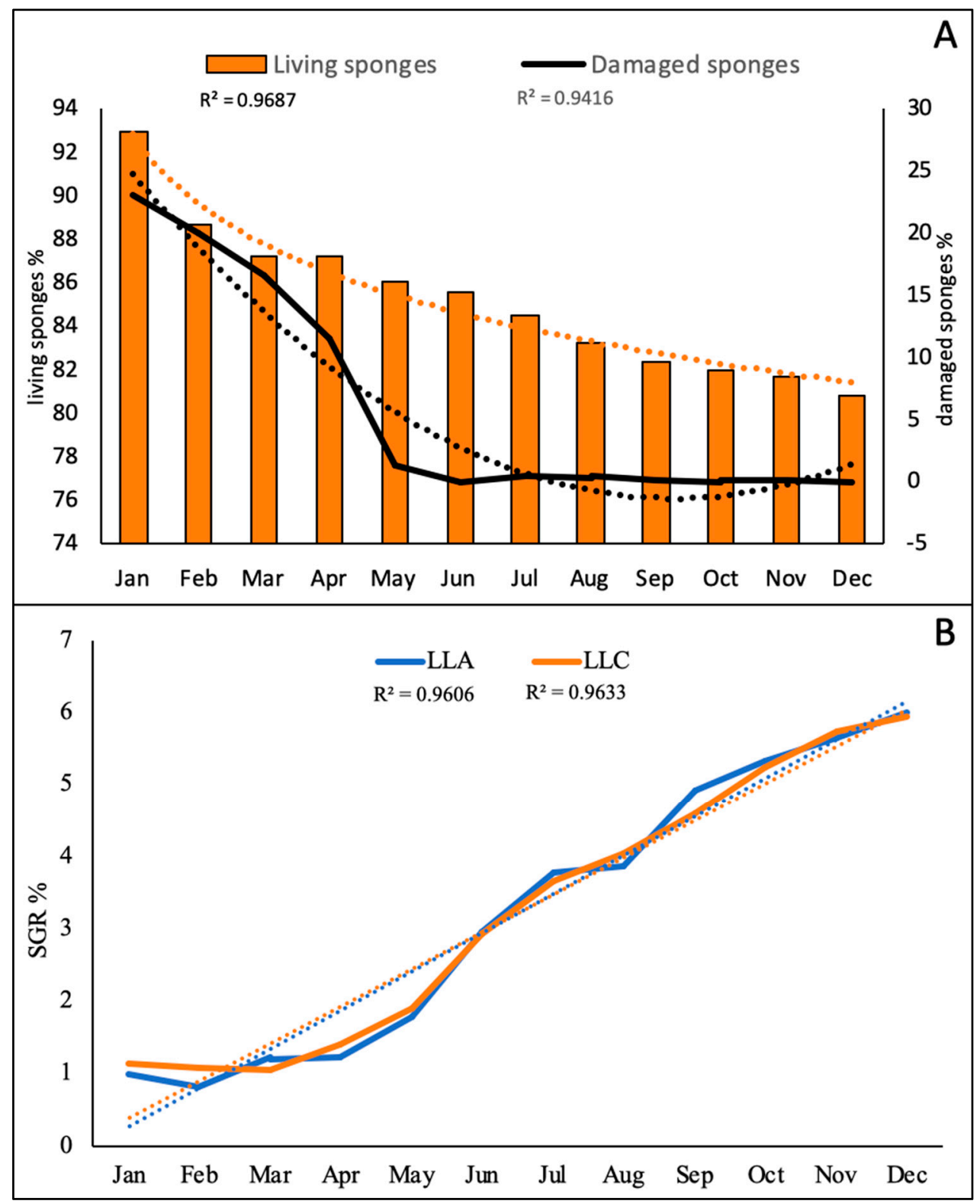

Figure 7. (A): Relationship between survival (histogram), damaged specimens (solid line) of reared sponges and month of observation. Survival is indicated by the percentage of live individuals observed in each month; individuals of damaged sponges are indicated with the solid line. (B): Relationship between the specific growth rate (SGR) of the reared sponges and the month of observation (from January to December 2019).

\subsection{Growing of Macroalgae}

The bimonthly monitoring of the well-being and growth of the macroalgae placed in the experimental plant showed interesting growth performances, with high survival rates and significant increases in the biomass produced in short time intervals (Figure 9A). As regards C. linum, from October 2018 until March 2019, low mortality values were recorded. Moreover, a medium specific growth rate (SGR) equal to 5\% was calculated in the six-month trial. Interestingly, in the first 11 days of cultivation, an $11 \%$ SGR was measured for this species. At the end of March, C. linum thalli underwent fragmentation followed by a rapid decay, so cultivation was cut short and biomass was harvested. Subsequently, in April 2019, the red alga Gracilaria bursa-pastoris was tested and remained in the cultivation plant until the end of summer 2019, when a dystrophic crisis occurred in the basin and 
problems with pathogens and epiphytes of seaweeds arose (Figure 9B). Such fouling led to extensive loss of biomass and considerable quality deterioration. However, it should be stressed that, until the end of August, this second selected algal species also increased considerably in biomass and a good increase in wet weight was recorded with a medium daily biomass increase of $4.4 \%$.

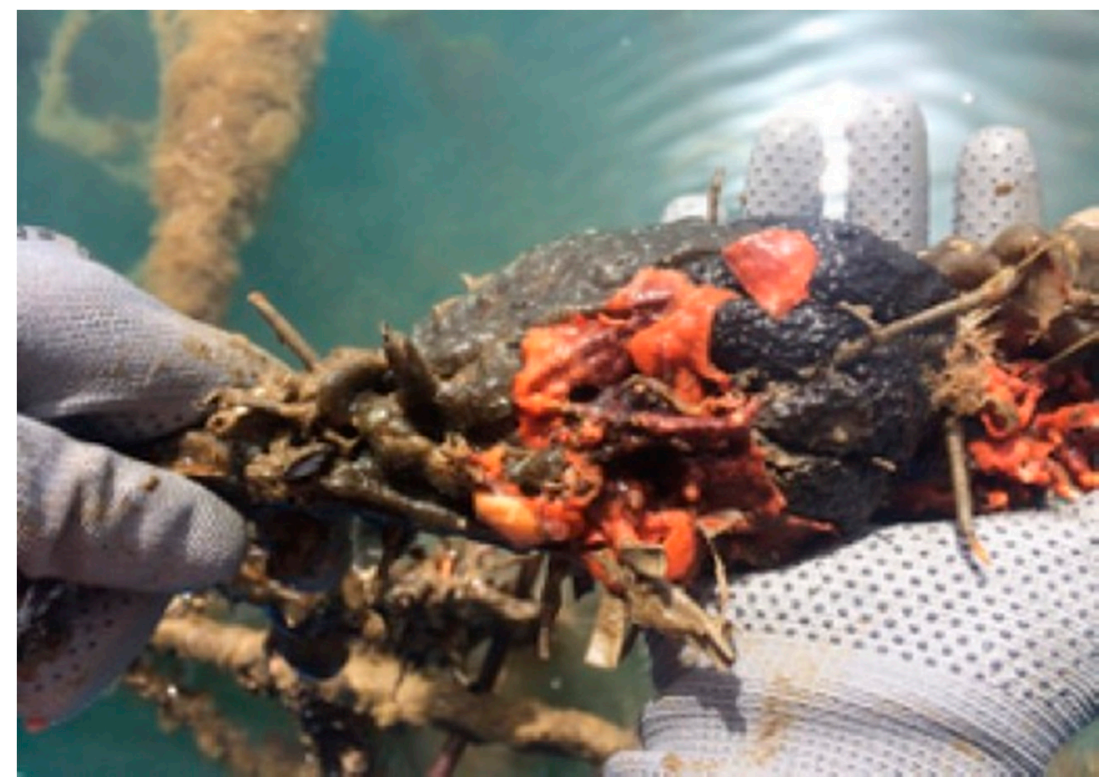

Figure 8. A specimen of Sarcotragus spinosulus covered by sabellids, bryozoans and ascidians. The picture was taken during the April 2019 monitoring at the IMTA Remedia Life plant in Taranto.

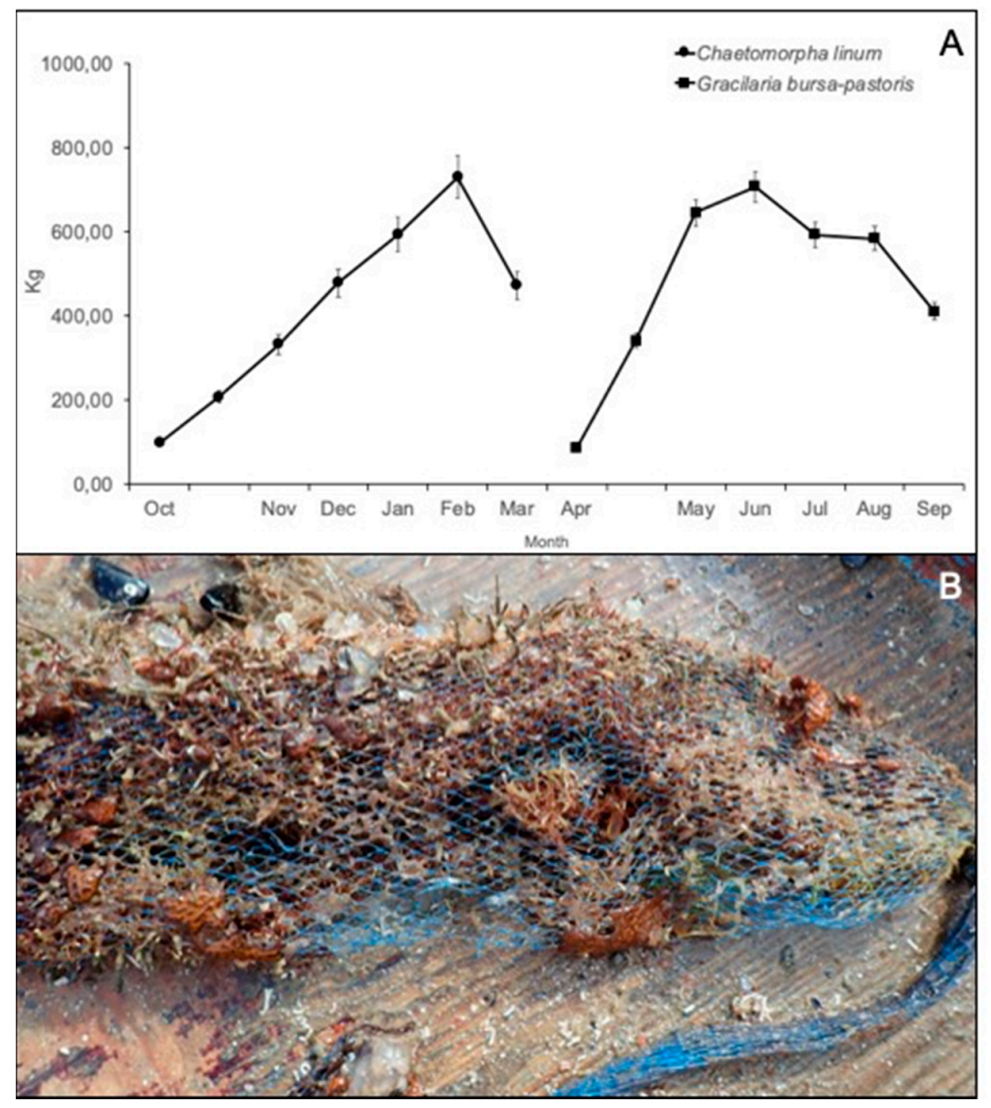

Figure 9. (A): trend of growth of the two cultivated seaweeds. (B): photograph of a retina from Gracilaria bursa-pastoris showing the fouling covering. 
Interestingly, in the first 7 days of cultivation of Gracilaria bursa-pastoris, the mean SGR value was $11.1 \%$, with a maximum of $14.6 \%$. The interruption of the algal biomass production due to the dystrophic crisis and the development of epiphytes was particularly evident at the end of September. On account of these results, we calculated the possible production of a total algal biomass of about 1.4 tonnes, i.e., ca. 0.84 tonnes for C. linum and ca. 0.56 tons for G. bursa-pastoris.

\section{Discussion and Conclusions}

The experimentation of the polyculture system utilized within the Remedia Life project started about two years ago, and in this first cycle of production, we tried to solve some critical points, one of which was linked to the development of simple and useful practices to obtain a large amount of biomass of bioremediators. This was particularly relevant concerning the recruitment of polychaetes on collectors with the recovery of adults from adjacent artificial substrates, avoiding the removal from wild populations.

In the present paper, the results of the polyculture of three selected components (sponges, polychaetes and macroalgae) are reported. All these organisms, although needing different methodological approaches, were reared/cultivated in the same long lines. On the collectors utilized for rearing the sabellid S. spallanzanii (henceforth called Sabella), a macrofaunal colonization pattern was followed in order to understand the possibility of both a natural sabellid recruitment and the settlement of other fouler species that can cooperate in the bioremediation activity. For this reason, the collectors for polychaetes were never cleaned from the fouling, being also Sabella-protected by the covering through long tubes that run away from the substrate. By contrast, the collectors for sponge and macroalgae rearing suffered from fouling covering and needed periodical cleaning during the growth of the target species.

\subsection{Performances of the Target Species}

\subsubsection{Polychaetes}

Filter feeder polychaete-rearing for bioremediation purposes is a novelty all around the world. An experiment was carried out in an area of mussel farming in south-east Brazil, where the species Branchiomma luctuosum was obtained with a technique similar to that utilized in the present paper, obtaining settlers on vertically positioned floating structures [85]. However, the authors refer to rearing for ornamental purposes and do not mention their bioremediation activity which, instead, could be of paramount importance in the treatment of farming waters, and the biomass can be considered as a by-product of this activity. Excluding this paper, all experiences of sabellid rearing must be referred to our team's experience, the first one carried out in a land-based fish farm with recycled water [36], followed by another experiment conducted at a small scale in the sea [51] and coupled with a mollusc farm [52].

One of the aims of the first year of observations within the IMTA system was to analyze the possibility to obtain recruits in situ. Indeed, the techniques utilized in previous experiences proved unthinkable to be applied at larger scales since requiring a workforce leading to prohibitive costs [36,52]. The method presently utilized, focused on obtaining recruitment directly on bare collectors, is very simple and does not require any management cost after the immersion of collectors. The method is based on strong local knowledge on the fouling community settlement dynamic coupled with the knowledge of sabellid life cycles and their recruitment dynamics $[43,44,75,86,87]$, and is linked to the massive presence in the environment of this species.

The pattern of community development observed on the bare vertical collectors utilized, containing, at the base, individuals of Sabella, agrees with previous studies on the fouling community obtained with the use of panels [75]. The macrofouling colonization investigated in the bare collector was followed until a "stable point" was reached after almost nine months; at this point, all the structures were characterized by a shallow assemblage (0-3 m), dominated by $M$. galloprovincialis, and a deeper 
assemblage (3-10 m), dominated almost exclusively by sabellid worms. These final assemblages obtained are perfectly in line with the endpoint observed in the same period and in the same area by Lezzi and Giangrande [75], utilizing PVC panels, with depth and immersion durations having a significant effect on the evolution of fouling community structures on collectors.

Similar succession was observed in the two long lines examined, with no effect of the position on the variation in species composition nor on abundance. With both long lines, the assemblage converged in a "stable state" dominated by late successional species, namely M. galloprovincialis and Sabella dominating the shallower and deeper assemblages, respectively. This deeper assemblage appeared very interesting, showing a coverage due almost exclusively to worms, with the target species contributing up to $85 \%$, whilst other species, such as the allochthonous B. luctuosum and $B$. boholense, occurred with sporadic presence throughout the year. The success of Sabella was due to the immersion time matching with the spawning period of the species in the Taranto sea [86], leading to a massive recruitment since January and preventing the settlement of mussels that commonly recruit later (April-June).

The growth of Sabella was monitored for up to a year, allowing to estimate the possible annual yield. Morphometric measurements started in April 2019 because, during the first life period, an in situ measurement of the worm density showed particularly dangerous results due the impossibility of handling the tubes without inducing stress phenomena capable of affecting their survival. After one year of their maintenance in the sea, each worm reached up to $10 \mathrm{~cm}$ in length and $2.5 \mathrm{~g}$ in wet weight. Collectors showed a density of about 100 worms per linear meter, with $50 \%$ of mortality occurring from June to December. However, it is probable that this decrease in density was mainly due to the detachment of the worms from the collector due to the weight of the fouling, because worms were observed to always be in good condition and never suffered from overgrowth of different organisms. From the performance of the first cycle, it a yearly production of about 0.36 tonnes of worms (wet weight) was estimated.

\subsubsection{Sponges}

Sponge mariculture has received increased attention over recent decades [55,88-93], and in the Mediterranean area, experiences using IMTA with fish and sponges have been recently performed for experimental purposes $[42,44,54,94,95]$. Laboratory and field experiments of sponge cultures have been conducted toward production of biomass for extraction of bioactive compounds, highlighting that the in situ sponge culture may be suitable for the eco-sustainable production of biomass for some target species [96]. The results of a life cycle assessment (LCA) conducted at a sea-based farm's in situ cultivation of the sponge Sarcotragus spinosulus by Perez-Lopez et al. [81] demonstrated that the cultivation aiming to extract bioactive molecules had a more environmentally-friendly performance than the subsequent downstream processes (solvent extraction), which were the main cause of the impact.

The sponge rearing performances obtained during the first production cycle have highlighted the high capacity of S. spinosulus to grow and survive in vertical structures, increasing its biomass constantly and rather fast. The mortality values obtained during the monthly monitoring ranged between $7 \%$ and $19.16 \%$, reaching around $20 \%$ at the end of the first year of observations. This was perfectly in line with the forecast and largely due to an initial death following collection, cutting and cultivation; subsequent mortality during the spring months was mainly due to competition phenomena with other filter feeder organisms, such as ascidians, mussels and polychaetes, which often outgrew the sponge, in part causing their detachment and partly suffocating it. For this reason, it was necessary to often intervene with removal of the fouling from the modules. This operation, normally carried out with M. galloprovincialis, exposing the structures to the air to cause the detachment of the epibionts, in reality, cannot be performed as it is for the sponges. The sponges, in fact, do not have a great chance of resisting dehydration for many hours and the cleaning operations must be carried out manually, often operating in immersion in the hottest periods. 
The analysis of the sponges showing signs of stress but still living, such as not completely healed tissue or bacterial patina, suggests a great capacity for regeneration and recovery of the sponges grown in IMTA. In fact, the initial damage values, up to about $23 \%$, when mortality was already $7 \%$, did not translate into an increase in mortality which, on the contrary, showed a partially independent pattern.

The first cycle of sponge rearing has shown extremely promising results in all the long lines: in October 2018, about $300 \mathrm{~L}$ of sponges were placed in the multitrophic rearing plant, which, in the first months, shrunk to about $220 \mathrm{~L}$. The biomass loss is essentially attributable to the initial mortality due to manipulation, and it had a completely exceptional value since no further decreases in volume were recorded, but, on the contrary, biomass regularly increased until the end. The evaluation of the rearing performance of the sponges after the initial stress has highlighted how, in December 2019, the total volume almost doubled, reaching a net production of about $200 \mathrm{~L}$ of sponge biomass, demonstrating its ability to adapt to the IMTA plant of Taranto. In addition to the good rearing performance, therefore, the reared sponge explants have shown good resistance to environmental stress, allowing to consider promising the use of this species in integrated mariculture systems.

\subsubsection{Macroalgae}

Seaweed polyculture has a recent history in Europe, mainly addressed to kelp species (e.g., Alaria esculenta, Laminaria digitata, and Saccharina latissima) reared with mussels [97]. Two of the main constraints to the development of IMTA with seaweeds are the seasonality of their life cycle and the scarcity of seed-stocks immediately available [98]. To overcome these problems, in the experimental IMTA plant set up in the Taranto sea, two species with different growth seasons, Chaetomorpha linum and Gracilaria bursa-pastoris, were maintained for the first time in co-culture with bioremediation macroinvertebrates during alternate seasons. To date, no information is available on C. linum cultivation either in monoculture or in an IMTA attempt anywhere, except a growth test performed in Canada, in tanks with different kinds of municipal wastewaters, in order to assess the bioremediation capacity. A SGR between $0.8-6.5 \%$ in 12 days of cultivation was calculated in that case [99]. Our values are included in this interval, but they are medium values calculated from a longer period of about six months. In the first 11 days of cultivation, an $11 \%$ SGR was determined, showing that the species has a moderate/high capacity of utilizing nutrients coming from the nearby fish cages for its own growth. Concerning Gracilaria bursa-pastoris, only in Israel has an experimental polyculture with Ulva rigida and Sparus aurata been attempted; the species reached a maximum SGR of $10 \%$ in specimens hung to the fish cages, and values of about $6 \%$ at the control site $100 \mathrm{~m}$ from the fish cages [100]. These values seem much higher in comparison with those calculated during the Life Remedia cultivation, which, conversely, showed results slightly higher than those recorded in autumn (i.e., 3.5\%) and in spring (i.e., 3.2\%) in a three-seaweed cultivation plant (i.e., Chondracanthus teedei, Gracilariopsis longissimi and Gracilaria bursa-pastoris) set up in an eutrophic embayment in southern Spain [101]. However, it should be considered that the Israel experiment lasted only 14 days, while the Spanish experiment was carried out for 3 weeks in autumn and for 6 weeks in spring and was not realized in an integrated polyculture. The medium value of G. bursa-pastoris SGR in the Taranto seas was calculated in an experiment lasting 163 days, which is about 5 months. However, in the first 7 days of cultivation, the mean measured SGR reached a value of $11.1 \%$ with a maximum of $14.6 \%$. These high values suggest, also for G. bursa-pastoris, that eutrophic conditions, most conceivably nitrogen from the fish cages, foster thalli growth. However, considering the noticeable decrease of the growth rate that occurred for both species up to the end of the selected cultivation period, nitrogen may have become a limiting factor for their growth in the long run. Another obstacle to the development of cultured seaweed biomass could be the biofouling by epiphytes. In this respect, the abundant epiphyte blooming observed in September 2019 could have adversely affected G. bursa-pastoris growth, causing a limiting reduction in light penetration [102] as already observed in a preliminary IMTA experiment carried out in the Mar Piccolo of Taranto using mussels (Mytilus galloprovincialis), sabellids (Sabella spallanzanii) and seaweeds (Gracilaria dura) [72]. This phenomenon was also observed elsewhere. For example, in Norway, Saccharina latissima thalli 
are often hugely covered in late spring/early summer by both invertebrates (e.g., bryozoans, blue mussels, hydroids) and macroalgae [103]. This, in the worst case, causes considerable damages to seaweed production, so farmers consider it necessary to harvest $S$. latissima crops in late spring, possibly replacing them with some other species more resistant to fouling [103].

On account of these considerations, we suggest the realization, throughout the year, of two cycles of seaweed cultivation, one related to C. linum, starting in October and ending in February, and the other related to G. bursa-pastoris, starting in April and ending in early July. Moreover, a shorter rearing time could be advisable for seaweed in this innovative system in order to maximize their biomass production. A biweekly harvesting of biomass returning to the original weight could be optimal in order to lighten the socks and make more space for a new production; this will be the strategy applied to the next production cycle.

\subsection{Conclusive Remarks}

The biological assemblage obtained in the IMTA system realized in the Gulf of Taranto represents an interesting tool to exploit for several reasons: ease of species cultivation, efficiency of the filtering system and crop diversification of valuable by-products which could increase the biomass production of an aquaculture site, opening new commercial horizons.

The method for sabellid breeding applied here demonstrated that a conspicuous amount of worm biomass can be obtained, coming mostly by filtering the wastes of the aquaculture farm. On the basis of some data from previous experimetns [36], a requirement of five quintals of polychaetes to process the yearly quantity of wastes was computed; this amount is slight higher than that produced during the first year of observations. However, the presence on the collectors of other bioremediators must also be considered, as well as sponges and macroalgae having a high efficiency in bioremediation of seawater nutrient enrichment and removal of heavy metals [48,99-101,104-108]. Although mass balance with net removal of wastes is still under study, preliminary analyses of benthic communities under cages have shown relevant positive structural changes (unpublished data). In this context, the fouling community associated with the collectors is noteworthy. Sessile organisms were mainly ascidians, whose filtration efficiency has already been investigated by our group [109]. The presence of rearing structures increases indeed biodiversity, modifying the spatial structure of the original substrates with positive repercussions on the fauna composition of the underlying hard and inconsistent substrates. If, however, increasing the biomass of fouling leads to an advantage in the removal of organic substance, it should be emphasized that an accumulation of biomass could have negative effects if it remains for a long time in the area, or if it even had to detach and accumulate on the bottom. For this reason, it is necessary to periodically remove the biomass obtained, directing it towards commercial and processing chains that are not yet well defined, definitively removing the organic substance from the plant.

The different reared target species, sabellid, sponges and seaweeds, need different periods of maintenance in the system, from a very short period for macroalgae, where a biweekly harvesting of biomass was hypothesized as the best strategy, to at least one year for sabellid and sponges. After the first year, only half of the collectors were harvested, leaving the others operating in situ in order to evaluate the produced biomass after a two-year cycle. Moreover, the adults remaining in the system could also continue to act as reproducers for the new cycle.

Sponges open up new perspectives related to their use in different fields, representing a valuable by-product of the IMTA system due to the potential for new biomaterials, biomedical applications and pharmaceutical products [110]. Several natural products can be extracted from this species, and among them, polyprenylhydroquinones [111] drew particular attention due to their wide spectrum of bioactivities (antibacterial, antiviral, anti-inflammatory and cytotoxic) [79].

Macroalgae could be an important by product too, highlighting their capacity of producing bioactive compounds for multiple applications $[49,78,112-114]$. In particular, in the lipidic extract of $C$. linum from the Taranto sea, Stabili et al. [49] demonstrated the existence of antibacterial and antioxidant activity against common pathogens in aquaculture, such as Vibrio ordalii and Vibrio vulnificus. It is 
likely that the antibacterial activity is linked to the high density of linolenic acid, while carotenoids and chlorophylls could be responsible for the antioxidant activity. Moreover, the presence of omega- 3 and omega- 6 fatty acids could make it an innovative ingredient in fortified food, and polyhydroxybutyrrate could be used in the production of biodegradable bioplastics. Notwithstanding the proved utility of macroalgae cultivation and the possible setting up of new economic scenarios, Europe is still several steps behind regarding effective establishment of a seaweed industry. To this end, in order to create the right conditions for the development of a sustainable European bioeconomy founded on macroalgal biomass, Asian models, both technical and economic, have to be used as a point of departure, making aquaculture enterprises and policy makers acquainted with the risks and advantages related to seaweed cultivation in IMTA systems. The present study could represent a first step towards this direction.

Lastly, the utilization of Sabella and sponge biomass is still under investigation, including market analysis, those being actual by-products from IMTA systems.

Author Contributions: Conceptualization, A.G., C.P. and C.L., methodology, A.G., M.L., E.C. and A.P.; validation, A.G.; formal analysis, D.A., J.B., R.T. and G.B.; Investigation, D.A., J.B., M.L., R.T. and G.B.; writing-original draft preparation, A.G., C.P., A.P., L.S. and C.L.; Writing-Review \& Editing, A.G., C.P., A.P., G.C. and C.L.; supervision, A.G., C.P. and C.L.; Project Administration, A.G., L.S., G.C. and C.L. All authors have read and agreed to the published version of the manuscript.

Funding: This research was funded by the European Community (Remedia Life project LIFE16 ENV/IT/000343).

Aknowledgments: Thanks are due to Sig. Giuseppe Portacci and Patrizia Ricci for their technical help both in the field and in the laboratory. Acknowledgments are also due to two anonymous reviewers who have critically contributed to the writing of this manuscript.

Conflicts of Interest: The authors declare no conflict of interest.

\section{References}

1. Karakassis, I.; Tsapakis, M.; Hatziyanni, E.; Papadopoulou, K.N.; Plaiti, W. Impact of cage farming of fish on the seabed in three Mediterranean coastal areas. ICES J. Mar. Sci. 2000, 57, 1462-1471. [CrossRef]

2. Mazzola, A.; Sarà, G. The effect of fish farming organic waste on food availability for bivalve molluscs (Gaeta Gulf, Central Tyrrhenian, MED): Stable carbon isotopic analysis. Aquaculture 2001, 192, 361-379. [CrossRef]

3. Sarà, G.; Zenone, A.; Tomasello, A. Growth of Mytilus galloprovincialis (mollusca, bivalvia) close to fish farms: A case of integrated multi-trophic aquaculture within the Tyrrhenian Sea. Hydrobiologia 2009, 636, 129-136. [CrossRef]

4. Moraitis, M.; Papageorgiou, N.; Dimitriou, P.D.; Petrou, A.; Karakassis, I. Effects of offshore tuna farming on benthic assemblages in the Eastern Mediterranean. Aquac. Environ. Interact. 2013, 4, 41-51. [CrossRef]

5. Granada, L.; Sousa, N.; Lopes, S.; Lemos, M.F.L. Is integrated multitrophic aquaculture the solution to the sectors' major challenges? A review. Rev. Aquac. 2016, 8, 283-300. [CrossRef]

6. Hughes, A.D.; Black, K.D. Going beyond the search for solutions: Understanding trade-offs in European integrated multi-trophic aquaculture development. Aquac. Environ. Interact. 2016, 8, 191-199. [CrossRef]

7. Barrington, K.; Chopin, T.; Robinson, S. Integrated multi-trophic aquaculture (IMTA) in marine temperate waters. In Integrated Mariculture: A Global Review; Soto, D., Ed.; FAO Fisheries and Aquaculture Technical Paper; FAO: Rome, Italy, 2009; Volume 529, pp. 7-46.

8. Fang, J.; Zhang, J.; Xiao, T.; Huang, D.; Liu, S. Integrated multi-trophic aquaculture (IMTA) in Sanggou Bay, China. Aquac. Environ. Interact. 2016, 8, 201-205. [CrossRef]

9. Heilskov, A.C.; Alperin, M.; Holmer, M. Benthic fauna bio-irrigation effects on nutrient regeneration in fish farm sediments. J. Exp. Mar. Biol. Ecol. 2006, 339, 204-225. [CrossRef]

10. Kinoshita, K.; Tamaki, S.; Yoshioka, M.; Srithonguthai, S.; Kunihiro, T.; Ohwada, K.; Tsutsumi, H. Bioremediation of organically enriched sediment deposited below fish farms with artificially mass-cultured colonies of a deposit-feeding polychaete Capitella sp. I. Fish. Sci. 2008, 74, 77-87. [CrossRef]

11. Wang, X.; Olsen, L.M.; Reitan, K.I.; Olsen, Y. Discharge of nutrient wastes from salmon farms: Environmental effects, and potential for integrated multi-trophic aquaculture. Aquac. Environ. Interact. 2012, 2, $267-283$. [CrossRef] 
12. Bergström, P.; Carlsson, M.S.; Lindegarth, M.; Petersen, J.K.; Lindegarth, S.; Holmer, M. Testing the potential for improving quality of sediments impacted by mussel farms using bioturbating polychaete worms. Aquac. Res. 2017, 48, 161-176. [CrossRef]

13. Israel, D.; Lupatsch, I.; Angel, D.L. Testing the digestibility of seabream wastes in three candidates for integrated multi-trophic aquaculture: Grey mullet, sea urchin and sea cucumber. Aquaculture 2019, 510, 364-370. [CrossRef]

14. Jansen, H.M.; Hansen, P.K.; Brennan, N.; Dahlgren, T.G.; Fang, J.; Nederlof, M.A.J.; Strohmeier, T.; Sveier, H.; Strand, $\varnothing$. Enhancing opportunistic polychaete communities under fish farms: An alternative concept for integrated aquaculture. Aquac. Environ. Interact. 2019, 11, 331-336. [CrossRef]

15. Cromey, C.J.; Nickell, T.D.; Black, K.D. DEPOMOD-Modelling the deposition and biological effects of waste solids from marine cage farms. Aquaculture 2002, 214, 211-239. [CrossRef]

16. Sarà, G.; Scilipoti, D.; Mazzola, A.; Modica, A. Effects of fish farming waste to sedimentary and particulate organic matter in a southern Mediterranean area (Gulf of Castellammare, Sicily): A multiple stable isotope study ( $\$ \delta \$ 13 \mathrm{C}$ and $\$ \delta \$ 15 \mathrm{~N})$. Aquaculture 2004, 234, 199-213. [CrossRef]

17. Sarà, G.; Scilipoti, D.; Milazzo, M.; Modica, A. Use of stable isotopes to investigate dispersal of waste from fish farms as a function of hydrodynamics. Mar. Ecol. Prog. Ser. 2006, 313, 261-270. [CrossRef]

18. Sarà, G.; Lo Martire, M.; Buffa, G.; Mannino, A.M.; Badalamenti, F. The fouling community as an indicator of fish farming impact in Mediterranean. Aquac. Res. 2007, 38, 66-75. [CrossRef]

19. Black, K.D. Sustainability of aquaculture. In Environmental Impacts of Aquaculture; Black, K.D., Ed.; Sheffield Academic Press: Sheffield, UK, 2001; pp. 199-212.

20. Angel, D.L.; Eden, N.; Breitstein, S.; Yurman, A.; Katz, T.; Spanier, E. In situ biofiltration: A means to limit the dispersal of effluents from marine finfish cage aquaculture. Hydrobiologia 2002, 469, 1-10. [CrossRef]

21. Angel, D.L.; Spanier, E. An application of artificial reefs to reduce organic enrichment caused by net-cage fish farming: Preliminary results. ICES J. Mar. Sci. 2002, 59, S324-S329. [CrossRef]

22. Hughes, D.J.; Cook, E.J.; Sayer, M.D.J. Biofiltration and biofouling on artificial structures in Europe: The potential for mitigating organic impacts. Oceanogr. Mar. Biol. 2005, 43, 123.

23. Chopin, T.; Robinson, S.M.C.; Troell, M.; Neori, A.; Buschmann, A.; Fang, J.G. Multi-trophic integration for sustainable marine aquaculture. In The Encyclopaedia of Ecology, 1st ed.; Jørgensen, S.E., Fath, B.D., Eds.; Elsevier: Oxford, UK, 2008; Volume 3, pp. 2463-2475.

24. Chopin, T.; Cooper, J.A.; Reid, G.; Cross, S.; Moore, C. Open-water integrated multi-trophic aquaculture: Environmental biomitigation and economic diversification of fed aquaculture by extractive aquaculture. Rev. Aquac. 2012, 4, 209-220. [CrossRef]

25. Ren, J.S.; Stenton-Dozey, J.; Plew, D.R.; Fang, J.; Gall, M. An ecosystem model for optimising production in integrated multitrophic aquaculture systems. Ecol. Modell. 2012, 246, 34-46. [CrossRef]

26. Woods, C.M.C.; Floerl, O.; Hayden, B.J. Biofouling on Greenshell mussel (Perna canaliculus) farms: A preliminary assessment and potential implications for sustainable aquaculture practices. Aquac. Int. 2012, 20, 537-557. [CrossRef]

27. Gonzalez-Silvera, D.; Izquierdo-Gomez, D.; Fernandez-Gonzalez, V.; Martínez-López, F.J.; López-Jiménez, J.A.; Sanchez-Jerez, P. Mediterranean fouling communities assimilate the organic matter derived from coastal fish farms as a new trophic resource. Mar. Pollut. Bull. 2015, 91, 45-53. [CrossRef] [PubMed]

28. Montalto, V.; Rinaldi, A.; Ape, F.; Mangano, M.C.; Gristina, M.; Sarà, G.; Mirto, S. Functional role of biofouling linked to aquaculture facilities in Mediterranean enclosed locations. Aquac. Environ. Interact. 2020, 12, 11-22. [CrossRef]

29. Navarrete-Mier, F.; Sanz-Lázaro, C.; Marín, A. Does bivalve mollusc polyculture reduce marine fin fish farming environmental impact? Aquaculture 2010, 306, 101-107. [CrossRef]

30. Mahmood, T.; Fang, J.; Jiang, Z.; Zhang, J. Carbon and nitrogen flow, and trophic relationships, among the cultured species in an integrated multi-trophic aquaculture (IMTA) bay. Aquac. Environ. Interact. 2016, 8, 207-219. [CrossRef]

31. Ning, Z.; Liu, S.; Zhang, G.; Ning, X.; Li, R.; Jiang, Z.; Fang, J.; Zhang, J. Impacts of an integrated multi-trophic aquaculture system on benthic nutrient fluxes: A case study in Sanggou Bay, China. Aquac. Environ. Interact. 2016, 8, 221-232. [CrossRef] 
32. Sanz-Lazaro, C.; Sanchez-Jerez, P. Mussels do not directly assimilate fish farm wastes: Shifting the rationale of integrated multi-trophic aquaculture to a broader scale. J. Environ. Manag. 2017, 201, 82-88. [CrossRef]

33. Giangrande, A.; Lezzi, M.; Del Pasqua, M.; Pierri, C.; Longo, C.; Gravina, M.F. Two cases study of fouling colonization patterns in the Mediterranean sea in the perspective of integrated aquaculture system. Aquac. Rep. 2020, in press. [CrossRef]

34. Badalamenti, F.; D'anna, G.; Gristina, M.; Scalisi, M.; Tumbiolo, L. Remarks on a method to quantify the total biomass of a benthic community on artificial substrata. Rapp. Comm. Int. Mer Mediterr. 1992, 33, 377.

35. Bannister, J.; Sievers, M.; Bush, F.; Bloecher, N. Biofouling in marine aquaculture: A review of recent research and developments. Biofouling 2019, 35, 631-648. [CrossRef]

36. Giangrande, A.; Cavallo, A.; Licciano, M.; Mola, E.; Pierri, C.; Trianni, L. Utilization of the filter feeder polychaete Sabella spallanzanii Gmelin (Sabellidae) as bioremediator in aquaculture. Aquac. Int. 2005, 13, 129-136. [CrossRef]

37. Licciano, M.; Stabili, L.; Giangrande, A. Clearance rates of Sabella spallanzanii and Branchiomma luctuosum (Annelida: Polychaeta) on a pure culture of Vibrio alginolyticus. Water Res. 2005, 39, 4375-4384. [CrossRef] [PubMed]

38. Cavallo, D.; Pusceddu, A.; Danovaro, R.; Giangrande, A. Particulate organic matter uptake rates of two benthic filter-feeders (Sabella spallanzanii and Branchiomma luctuosum) candidates for the clarification of aquaculture wastewaters. Mar. Pollut. Bull. 2007, 54, 622-625. [CrossRef] [PubMed]

39. Stabili, L.; Schirosi, R.; Licciano, M.; Mola, E.; Giangrande, A. Bioremediation of bacteria in aquaculture waste using the polychaete Sabella spallanzanii. New Biotechnol. 2010, 27, 774-781. [CrossRef] [PubMed]

40. Stabili, L.; Licciano, M.; Lezzi, M.; Giangrande, A. Microbiological accumulation by the Mediterranean invasive alien species Branchiomma bairdi (Annelida, Sabellidae): Potential tool for bioremediation. Mar. Pollut. Bull. 2014, 86, 325-331. [CrossRef]

41. Stabili, L.; Licciano, M.; Giangrande, A.; Longo, C.; Mercurio, M.; Marzano, C.N.; Corriero, G. Filtering activity of Spongia officinalis var. adriatica (Schmidt) (Porifera, Demospongiae) on bacterioplankton: Implications for bioremediation of polluted seawater. Water Res. 2006, 40, 3083-3090. [CrossRef]

42. Stabili, L.; Licciano, M.; Longo, C.; Corriero, G.; Mercurio, M. Evaluation of microbiological accumulation capability of the commercial sponge Spongia officinalis var. adriatica (Schmidt) (Porifera, Demospongiae). Water Res. 2008, 42, 2499-2506. [CrossRef]

43. Longo, C.; Corriero, G.; Licciano, M.; Stabili, L. Bacterial accumulation by the Demospongiae Hymeniacidon perlevis: A tool for the bioremediation of polluted seawater. Mar. Pollut. Bull. 2010, 60, 1182-1187. [CrossRef]

44. Longo, C.; Cardone, F.; Corriero, G.; Licciano, M.; Pierri, C.; Stabili, L. The co-occurrence of the demosponge Hymeniacidon perlevis and the edible mussel Mytilus galloprovincialis as a new tool for bacterial load mitigation in aquaculture. Environ. Sci. Pollut. Res. 2016, 23, 3736-3746.

45. Giangrande, A.; Cavallo, A.; Pierri, C. Ammonium uptake of Cladophora prolifera (Chlorophyta, Cladophorales) a candidate species for bioremediation of aquaculture wastes. Thalass. Salentina 2007, 30, 107-116.

46. Alabiso, G.; Cecere, E.; Petrocelli, A.; Ricci, P. Ammonium uptake by Gracilaria dura (Rhodophyta, Gracilariales) from the Mar Piccolo of Taranto. Biol. Mar. Mediterr. 2007, 14, 268-269.

47. Alabiso, G.; Ricci, P.; Belmonte, M.; Petrocelli, A.; Cecere, E. Ammonium uptake by Gracilaria gracilis (Gracilariales, Rhodophyta) (Stackhouse) Steentoft, Irvine and Farnham, from the Mar Piccolo of Taranto. Biol. Mar. Mediterr. 2009, 16, 246-247.

48. Aquilino, F.; Paradiso, A.; Trani, R.; Longo, C.; Pierri, C.; Corriero, G.; De Pinto, M.C. Chaetomorpha linum in the bioremediation of aquaculture wastewater: Optimization of nutrient removal efficiency at the laboratory scale. Aquaculture 2020, 523, 735133.

49. Stabili, L.; Acquaviva, M.I.; Angilè, F.; Cavallo, R.A.; Cecere, E.; Del Coco, L.; Fanizzi, F.P.; Gerardi, C.; Narracci, M.; Petrocelli, A. Screening of Chaetomorpha linum lipidic extract as a new potential source of bioactive compounds. Mar. Drugs 2019, 17, 313.

50. Belghit, I.; Liland, N.S.; Gjesdal, P.; Biancarosa, I.; Menchetti, E.; Li, Y.; Waagbø, R.; Krogdahl, Å.; Lock, E.-J. Black soldier fly larvae meal can replace fish meal in diets of sea-water phase Atlantic salmon (Salmo salar). Aquaculture 2019, 503, 609-619.

51. Pierri, C.; Fanelli, G.; Giangrande, A. Experimental co-culture of low food-chain organisms, Sabella spallanzanii (Polychaeta, Sabellidae) and Cladophora prolifera (Chlorophyta, Cladophorales), in Porto Cesareo area (Mediterranean Sea). Aquac. Res. 2006, 37, 966-974. 
52. Giangrande, A.; Pierri, C.; Fanelli, G.; Schirosi, R.; Licciano, M.; Stabili, L. Rearing experiences of the polychaete Sabella spallanzanii in the Gulf of Taranto (Mediterranean Sea, Italy). Aquac. Int. 2014, 22, 1677-1688.

53. Pronzato, R.; Cerrano, C.; Cubeddu, T.; Lanza, S.; Magnino, G.; Manconi, R.; Pantelis, J.; Sara, A.; Sidri, M. Sustainable development in coastal areas: Role of sponge farming in integrated aquaculture. In Aquaculture and Water: Fish Culture, Shellfish Culture and Water Usage; Luiz, F., Aspeslagh, L., Van Craeynest, S., Eds.; Special Pubblication No. 26; European Aquaculture Society: Oostende, Belgium, 1998; pp. 231-232.

54. Manconi, R.; Cubeddu, T.; Corriero, G.; Pronzato, R. Commercial sponges farming as natural control of floating cages pollution. In New Species for Mediterranean Aquaculture; Enne, G., Greppi, G.F., Eds.; Biofutur Elsevier: Paris, France, 1999; pp. 269-274.

55. Corriero, G.; Longo, C.; Mercurio, M.; Marzano, C.N.; Lembo, G.; Spedicato, M.T. Rearing performance of Spongia officinalis on suspended ropes off the Southern Italian Coast (Central Mediterranean Sea). Aquaculture 2004, 238, 195-205.

56. Gökalp, M.; Wijgerde, T.; Sarà, A.; De Goeij, J.M.; Osinga, R. Development of an integrated mariculture for the collagen-rich sponge Chondrosia reniformis. Mar. Drugs 2019, 17, 29. [CrossRef]

57. Gökalp, M.; Kooistra, T.; Rocha, M.S.; Silva, T.H.; Osinga, R.; Murk, A.J.; Wijgerde, T. The Effect of Depth on the Morphology, Bacterial Clearance, and Respiration of the Mediterranean Sponge Chondrosia reniformis (Nardo, 1847). Mar. Drugs 2020, 18, 358. [CrossRef]

58. Mehbub, M.F.; Lei, J.; Franco, C.; Zhang, W. Marine sponge derived natural products between 2001 and 2010 : Trends and opportunities for discovery of bioactives. Mar. Drugs 2014, 12, 4539-4577. [CrossRef] [PubMed]

59. Chopin, T. Marine aquaculture in Canada: Well-established monocultures of finfish and shellfish and an emerging integrated multi-trophic aquaculture (IMTA) approach including seaweeds, other invertebrates, and microbial communities. Fisheries 2015, 40, 28-31. [CrossRef]

60. Neveux, N.; Bolton, J.J.; Bruhn, A.; Roberts, D.A.; Ras, M. The Bioremediation Potential of Seaweeds: Recycling Nitrogen, Phosphorus, and Other Waste Products. In Blue Biotechnology: Production and Use of Marine Molecules; La Barre, S., Bates, S.S., Eds.; John Wiley \& Sons, Inc.: Hoboken, NJ, USA, 2018; Volume 1, pp. 217-239.

61. Prazukin, A.V.; Anufriieva, E.V.; Shadrin, N.V. Is biomass of filamentous green algae Cladophora spp. (Chlorophyta, Ulvophyceae) an unlimited cheap and valuable resource for medicine and pharmacology? A review. In Reviews in Aquaculture; John Wiley \& Sons, Ltd.: Queensland, Australia, 2020; Volume 1.

62. Stabili, L.; Acquaviva, M.I.; Biandolino, F.; Cavallo, R.A.; De Pascali, S.A.; Fanizzi, F.P.; Narracci, M.; Petrocelli, A.; Cecere, E. The lipidic extract of the seaweed Gracilariopsis longissima (Rhodophyta, Gracilariales): A potential resource for biotechnological purposes? New Biotechnol. 2012, 29, 443-450. [CrossRef] [PubMed]

63. Stabili, L.; Acquaviva, M.I.; Biandolino, F.; Cavallo, R.A.; De Pascali, S.A.; Fanizzi, F.P.; Narracci, M.; Cecere, E.; Petrocelli, A. Biotechnological potential of the seaweed Cladophora rupestris (Chlorophyta, Cladophorales) lipidic extract. New Biotechnol. 2014, 31, 436-444. [CrossRef] [PubMed]

64. Freile-Pelegrín, Y.; Tasdemir, D. Seaweeds to the rescue of forgotten diseases: A review. Bot. Mar. 2019, 62, 211-226. [CrossRef]

65. Buck, B.H.; Troell, M.F.; Krause, G.; Angel, D.L.; Grote, B.; Chopin, T. State of the art and challenges for offshore integrated multi-trophic aquaculture (IMTA). Front. Mar. Sci. 2018, 5, 165. [CrossRef]

66. Ryther, J.H.; DeBoer, J.A.; Lapointe, B.E. Cultivation of seaweeds for hydrocolloids, waste treatment and biomass for energy conversion. In Proceedings of the Ninth Proc. Int. Seaweed Symp; SciencePress: Princeton, NJ, USA, 1977; Volume 9, pp. 1-16.

67. Friedlander, M.; Zelikovitch, N. Growth rates, phycocolloid yield and quality of the red seaweeds, Gracilaria sp., Pterocladia capillacea, Hypnea musciformis, and Hypnea cornuta, in field studies in Israel. Aquaculture 1984, 40, 57-66. [CrossRef]

68. Neori, A.; Shpigel, M.; Guttman, L.; Israel, A. Development of polyculture and integrated multi-trophic aquaculture (IMTA) in Israel: A review. Isr. J. Aquac. 2017, 69, 1-19.

69. Largo, D.B.; Diola, A.G.; Marababol, M.S. Development of an integrated multi-trophic aquaculture (IMTA) system for tropical marine species in southern Cebu, Central Philippines. Aquac. Rep. 2016, 3, 67-76. [CrossRef] 
70. Park, M.; Shin, S.K.; Do, Y.H.; Yarish, C.; Kim, J.K. Application of open water integrated multi-trophic aquaculture to intensive monoculture: A review of the current status and challenges in Korea. Aquaculture 2018, 497, 174-183. [CrossRef]

71. Kleitou, P.; Kletou, D.; David, J. Is Europe ready for integrated multi-trophic aquaculture? A survey on the perspectives of European farmers and scientists with IMTA experience. Aquaculture 2018, 490, 136-148. [CrossRef]

72. Cecere, E.; Fanelli, G.; Petrocelli, A.; Portacci, G.; Saracino, O.D. Polyculture of Gracilaria dura (Rhodophyta, Gracilariales) with mussels and polychaetes in the Mar Piccolo of Taranto: Preliminary results. In Proceedings of the 18th International Seaweed Symposium, Bergen, Norway, 20-25 June 2004.

73. Pierri, C.; Longo, C.; Giangrande, A. Variability of fouling communities in the Mar Piccolo of Taranto (Northern Ionian Sea, Mediterranean Sea). J. Mar. Biol. Assoc. UK 2010, 90, 159-167. [CrossRef]

74. Lezzi, M.; Del Pasqua, M.; Pierri, C.; Giangrande, A. Seasonal non-indigenous species succession in a marine macrofouling invertebrate community. Biol. Invasions 2018, 20, 937-961. [CrossRef]

75. Lezzi, M.; Giangrande, A. Seasonal and bathymetric effects on macrofouling invertebrates' primary succession in a mediterraenan non-indigenous species hotspot area. Mediterr. Mar. Sci. 2018, 19, 572-588. [CrossRef]

76. Del Pasqua, M.; Borghese, J.; Arduini, D.; Licciano, M.; Giangrande, A. Ex ante monitoring assessment of an aquaculture plan within the project remedia life: The use of polychaetes as indicators. Biol. Mar. Mediterr. 2019, 26, 53-56.

77. Pierri, C.; Colangelo, P.; Del Pasqua, M.; Longo, C.; Giangrande, A. Consequences of the experimental removal of Sabella spallanzanii (Gmelin, 1791) from the fouling assemblage of a Mediterranean harbour. Mediterr. Mar. Sci. 2019, 20, 476-486. [CrossRef]

78. Stabili, L.; Cecere, E.; Licciano, M.; Petrocelli, A.; Sicuro, B.; Giangrande, A. Integrated Multitrophic Aquaculture By-Products with Added Value: The Polychaete Sabella spallanzanii and the Seaweed Chaetomorpha linum as Potential Dietary Ingredients. Mar. Drugs 2019, 17, 677. [CrossRef]

79. Abed, C.; Legrave, N.; Dufies, M.; Robert, G.; Guérineau, V.; Vacelet, J.; Auberger, P.; Amade, P.; Mehiri, M. A new hydroxylated nonaprenylhydroquinone from the Mediterranean marine sponge Sarcotragus spinosulus. Mar. Drugs 2011, 9, 1210-1219. [CrossRef]

80. Mercurio, M.; Corriero, G.; Gherardi, M.; Baldacconi, R.; Gaino, E. Sexual reproduction in Sarcotragus spinosulus from two different shallow environments. Mar. Ecol. 2013, 34, 394-408.

81. Perez-Lopez, P.; Ledda, F.D.; Bisio, A.; Feijoo, G.; Perino, E.; Pronzato, R.; Manconi, R.; Moreira, M.T. Life cycle assessment of in situ mariculture in the Mediterranean Sea for the production of bioactive compounds from the sponge Sarcotragus spinosulus. J. Clean. Prod. 2017, 142, 4356-4368. [CrossRef]

82. Petrocelli, A.; Cecere, E.; Rubino, F. Successions of phytobenthos species in a Mediterranean transitional water system: The importance of long term observations. Nat. Conserv. 2019, 34, 217.

83. Abràmoff, M.D.; Magalhães, P.J.; Ram, S.J. Image processing with ImageJ. Biophotonics Int. 2004, 11, $36-42$.

84. Yong, Y.S.; Yong, W.T.L.; Anton, A. Analysis of formulae for determination of seaweed growth rate. J. Appl. Phycol. 2013, 25, 1831-1834. [CrossRef]

85. Carvalho, L.M.C.; Turra, A.; Alves, J.L.; De Almeida Marques, H.L. Capture of anemones and polychaetes in artificial collectors for ornamental purposes, effects of: Depth, deployment period, and time of immersion. Bol. Inst. Pesca 2019, 45. [CrossRef]

86. Giangrande, A.; Licciano, M.; Pagliara, P.; Gambi, M.C. Gametogenesis and larval development in Sabella spallanzanii (Polychaeta: Sabellidae) from the Mediterranean Sea. Mar. Biol. 2000, 136, 847-861. [CrossRef]

87. Longo, C.; Scalera-Liaci, L.; Manuel, M.; Corriero, G. Note sui poriferi del Mar Grande e del Mar Piccolo di Taranto (Mar Ionio). Biol. Mar. Mediterr. 2004, 11, 440-443.

88. Scalera Liaci, L.; Mercurio, M.; Palladino, F.; Massari, S.; Corriero, G. La spongicoltura: Una forma di maricoltura costiera compatibile con i vincoli di tutela delle aree protette. In Proceedings of the $29^{\circ}$ Congresso S.I.B.M., Ustica, Italy, 15-20 January 1998.

89. Scalera Liaci, L.; Mercurio, M.; Palladino, F.; Massari, S.; Corriero, G. L'allevamento di spugne commerciali nella Riserva Marina di Porto Cesareo (LE). Biol. Mar. Mediterr. 1999, 6, 110-118.

90. Mercurio, M.; Longo, C.; Nonnis Marzano, C.; Scalera Liaci, L.; Corriero, G. L'allevamento di spugne commerciali nella Riserva Naturale Marina 'Isola di Ustica'. Biol. Mar. Mediterr. 2003, 10, 462-464. 
91. Van Treeck, P.; Eisinger, M.; Müller, J.; Paster, M.; Schuhmacher, H. Mariculture trials with Mediterranean sponge species: The exploitation of an old natural resource with sustainable and novel methods. Aquaculture 2003, 218, 439-455. [CrossRef]

92. De Voogd, N.J. The mariculture potential of the Indonesian reef-dwelling sponge Callyspongia (Euplacella) biru: Growth, survival and bioactive compounds. Aquaculture 2007, 262, 54-64. [CrossRef]

93. De Caralt, S.; Sánchez-Fontenla, J.; Uriz, M.J.; Wijffels, R.H. In situ aquaculture methods for Dysidea avara (Demospongiae, Porifera) in the Northwestern Mediterranean. Mar. Drugs 2010, 8, 1731-1742. [CrossRef] [PubMed]

94. Osinga, R.; Sidri, M.; Cerig, E.; Gokalp, S.Z.; Gokalp, M. Sponge aquaculture trials in the East-Mediterranean Sea: New approaches to earlier ideas. Open Mar. Biol. J. 2010, 4, 74-81. [CrossRef]

95. Nemoy, P.; Spanier, E.; Angel, D. Sustainable cultivation of sponges in the Eastern Mediterranean Sea: Integrated aquaculture with fish farms. In Proceedings of the 10th World Sponge Conference, NUI, Galway, Ireland, 25-30 June 2017; p. 89.

96. Pronzato, R.; Manconi, R. Mediterranean commercial sponges: Over 5000 years of natural history and cultural heritage. Mar. Ecol. 2008, 29, 146-166. [CrossRef]

97. Holdt, S.L.; Edwards, M.D. Cost-effective IMTA: A comparison of the production efficiencies of mussels and seaweed. J. Appl. Phycol. 2014, 26, 933-945. [CrossRef]

98. Pereira, R.; Yarish, C.; Critchley, A.T. Seaweed aquaculture for human foods in land-based and IMTA systems. In Encyclopedia of Sustainability Science and Technology; Meyers, R.A., Ed.; Springer: New York, NY, USA, 2013; pp. 9109-9128.

99. Ge, S.; Champagne, P. Cultivation of the marine macroalgae Chaetomorpha linum in municipal wastewater for nutrient recovery and biomass production. Environ. Sci. Technol. 2017, 51, 3558-3566. [CrossRef]

100. Korzen, L.; Abelson, A.; Israel, A. Growth, protein and carbohydrate contents in Ulva rigida and Gracilaria bursa-pastoris integrated with an offshore fish farm. J. Appl. Phycol. 2016, 28, 1835-1845. [CrossRef]

101. Bermejo, R.; Cara, C.L.; Macías, M.; Sánchez-García, J.; Hernández, I. Growth rates of Gracilariopsis longissima, Gracilaria bursa-pastoris and Chondracanthus teedei (Rhodophyta) cultured in ropes: Implication for $\mathrm{N}$ biomitigation in Cadiz Bay (Southern Spain). J. Appl. Phycol. 2020, 32, 1-13. [CrossRef]

102. De Casabianca, M.L.; Marinho-Soriano, E.; Laugier, T. Growth of Gracilaria bursa-pastoris in a Mediterranean lagoon: Thau, France. Bot. Mar. 1997, 40, 29-38. [CrossRef]

103. Stévant, P.; Rebours, C.; Chapman, A. Seaweed aquaculture in Norway: Recent industrial developments and future perspectives. Aquac. Int. 2017, 25, 1373-1390. [CrossRef]

104. Giaccone, G.; Princi, M.; Rizzi Longo, L. Risposte morfologiche e fisiologiche di alghe marine in coltura all'inquinamento da liquami urbani ed industriale. Ing. Ambient. 1976, 6, 572-582.

105. Lavery, P.S.; McComb, A.J. The nutritional eco-physiology of Chaetomorpha linum and Ulva rigida in Peel Inlet, Western Australia. Bot. Mar. 1991, 34, 251-260. [CrossRef]

106. Menéndez, M.; Herrera-Silveira, J.; Comín, F.A. Effect of nitrogen and phosphorus supply on growth, chlorophyll content and tissue composition of the macroalga Chaetomorpha linum (OF Mull), Kutz, in a Mediterranean Coastal Lagoon. Sci. Mar. 2002, 66, 355-364. [CrossRef]

107. Beolchini, F.; Pennesi, C.; Testaferri, B.; Totti, C.; De Michelis, I.; Vegliò, F. Waste Biomass from Marine Environment as Arsenic and Lead Biosorbent. Adv. Mater. Res. 2009, 71-73, 597-600. [CrossRef]

108. He, J.; Chen, J.P. A comprehensive review on biosorption of heavy metals by algal biomass: Materials, performances, chemistry, and modeling simulation tools. Bioresour. Technol. 2014, 160, 67-78. [CrossRef]

109. Stabili, L.; Licciano, M.; Gravina, M.F.; Giangrande, A. Filtering activity on a pure culture of Vibrio alginolyticus by the solitary ascidian Styela plicata and the colonial ascidian Polyandrocarpa zorritensis: A potential service to improve microbiological seawater quality economically. Sci. Total Environ. 2016, 573, 11-18. [CrossRef]

110. Binnewerg, B.; Schubert, M.; Voronkina, A.; Muzychka, L.; Wysokowski, M.; Petrenko, I.; Djurović, M.; Kovalchuk, V.; Tsurkan, M.; Martinovic, R.; et al. Marine biomaterials: Biomimetic and pharmacological potential of cultivated Aplysina aerophoba marine demosponge. Mater. Sci. Eng. C 2020, 109, 110566. [CrossRef]

111. Cimino, G.; De Stefano, S.T.; Minale, L. Polyprenyl derivatives from the sponge Ircinia spinosula: 2-Polyprenylbenzoquinones, 2-polyprenylbenzoquinols, prenylated furans and a C-31 difuranoterpene. Tetrahedron 1972, 28, 1315-1324. [CrossRef] 
112. Yildiz, G.; Vatan, Ö.; Çelikler, S.; Dere, Ş. Determination of the phenolic compounds and antioxidative capacity in red algae Gracilaria bursa-pastoris. Int. J. Food Prop. 2011, 14, 496-502. [CrossRef]

113. Ramdani, M.; Elasri, O.; Saidi, N.; Elkhiati, N.; Taybi, F.A.; Mostareh, M.; Zaraali, O.; Haloui, B.; Ramdani, M. Evaluation of antioxidant activity and total phenol content of Gracilaria bursa-pastoris harvested in Nador lagoon for an enhanced economic valorization. Chem. Biol. Technol. Agric. 2017, 4, 1-7.

114. Janarthanan, M.; Senthil Kumar, M. The properties of bioactive substances obtained from seaweeds and their applications in textile industries. J. Ind. Text. 2018, 48, 361-401.

(C) 2020 by the authors. Licensee MDPI, Basel, Switzerland. This article is an open access article distributed under the terms and conditions of the Creative Commons Attribution (CC BY) license (http://creativecommons.org/licenses/by/4.0/). 